1 Review

\title{
Vitamin E-gene interactions in aging and inflammatory age-related diseases: Implications for treatment. A systematic review
}

\author{
${ }_{4}$ Q1 Eugenio Mocchegiani ${ }^{a, *}$, Laura Costarelli ${ }^{a}$, Robertina Giacconi ${ }^{a}$, Marco Malavolta ${ }^{a}$, \\ Andrea Basso ${ }^{\mathrm{a}}$, Francesco Piacenza ${ }^{\mathrm{a}}$, Rita Ostan ${ }^{\mathrm{b}}$, Elisa Cevenini ${ }^{\mathrm{b}}$, Efstathios S. Gonos ${ }^{\mathrm{c}}$, \\ Claudio Franceschi ${ }^{\mathrm{b}}$, Daniela Monti ${ }^{\mathrm{d}}$ \\ a Translation Center of Research of Nutrition and Ageing, Scientific and Technological Pole, Italian National Research Centres on Ageing (INRCA), Via \\ Birarelli 8, 60121 Ancona, Italy \\ ${ }^{\mathrm{b}}$ Department of Experimental Diagnostic and Specialty Medicine and Interdepartmental Centre "L. Galvani" (CIG), University of Bologna, Via San Giacomo \\ 12, 40126 Bologna, Italy \\ ${ }^{c}$ National Hellenic Research Foundation, Institute of Biology, Medicinal Chemistry and Biotechnology, 48 Vas. Constantinou Avenue, Athens 11635 , Greece \\ ${ }^{\mathrm{d}}$ Department of Clinical and Experimental Biomedical Sciences, University of Florence, Viale Morgagni 50, 50134 Florence, Italy
}

\section{A R T I C L E I N F O}

\section{Article history:}

Received 20 September 2013

Received in revised form

27 December 2013

Accepted 2 January 2014

Available online $\mathrm{xxx}$

Keywords:

Vitamin E-gene interactions

Immune system

Antioxidant activity

Inflammation

Aging

Longevity

\begin{abstract}
A B S T R A C T
Aging is a complex biological phenomenon in which the deficiency of the nutritional state combined with the presence of chronic inflammation and oxidative stress contribute to the development of many agerelated diseases. Under this profile, the free radicals produced by the oxidative stress lead to a damage of DNA, lipids and proteins with subsequent altered cellular homeostasis and integrity. In young-adult age, the cell has a complex efficient system to maintain a proper balance between the levels of free radicals and antioxidants ensuring the integrity of cellular components. In contrast, in old age this balance is poorly efficient compromising cellular homeostasis. Supplementation with Vitamin E can restore the balance and protect against the deteriorating effects of oxidative stress, progression of degenerative diseases, and aging. Experiments in cell cultures and in animals have clearly shown that Vitamin E has a pivotal role as antioxidant agent against the lipid peroxidation on cell membranes preserving the tissue cells from the oxidative damage. Such a role has been well documented in immune, endothelial, and brain cells from old animals describing how the Vitamin E works both at cytoplasmatic and nuclear levels with an influence on many genes related to the inflammatory/immune response. All these findings have supported a lot of clinical trials in old humans and in inflammatory age-related diseases with however contradictory and inconsistent results and even indicating a dangerous role of Vitamin $\mathrm{E}$ able to affect mortality. Various factors can contribute to all the discrepancies. Among them, the doses and the various isoforms of Vitamin $\mathrm{E}$ family $(\alpha, \beta, \gamma, \delta$ tocopherols and the corresponding tocotrienols) used in different trials. However, the more plausible gap is the poor consideration of the Vitamin E-gene interactions that may open new roadmaps for a correct and personalized Vitamin E supplementation in aging and agerelated diseases with satisfactory results in order to reach healthy aging and longevity. In this review, this peculiar nutrigenomic and/or nutrigenetic aspect is reported and discussed at the light of specific polymorphisms affecting the Vitamin E bioactivity.
\end{abstract}

(C) 2014 Published by Elsevier B.V.

\section{Contents}

1. Introduction

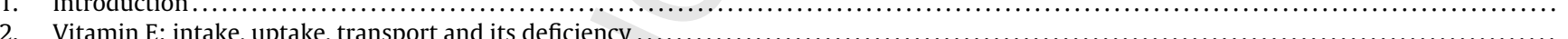

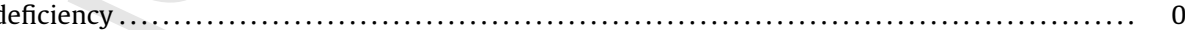

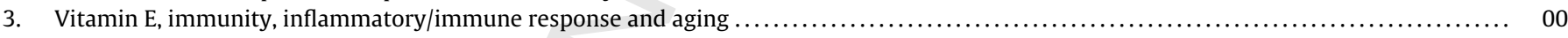

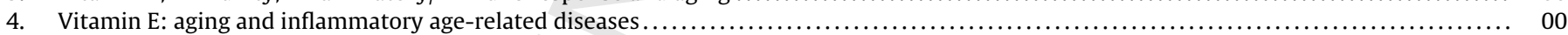

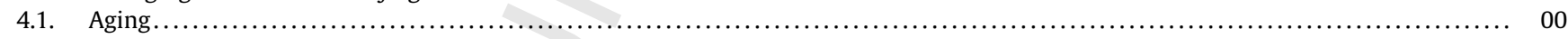

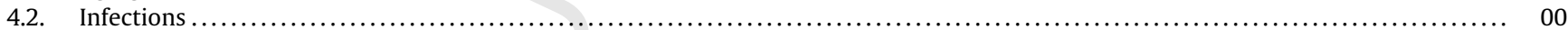

\footnotetext{
* Corresponding author at: Scientific and Technological Pole INRCA-IRCCS, Translation Center of Research of Nutrition and Ageing, Via Birarelli 8, 60121 Ancona, Italy. Tel.: +39 0718004216; fax: +39 071206791.

E-mail address: e.mocchegiani@inrca.it (E. Mocchegiani).
}

1568-1637/\$ - see front matter @ 2014 Published by Elsevier B.V. http://dx.doi.org/10.1016/j.arr.2014.01.001 
4.3. Atherosclerosis and cardiovascular diseases......

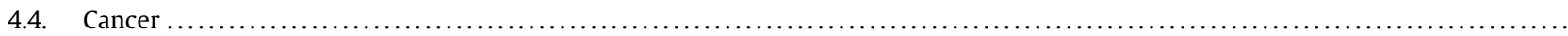

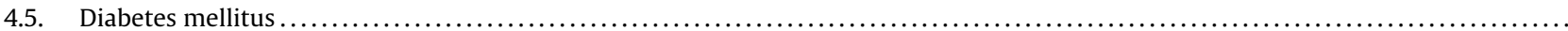

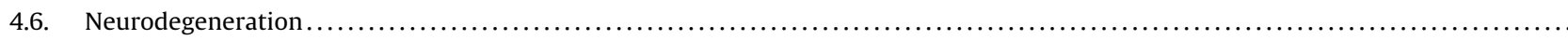

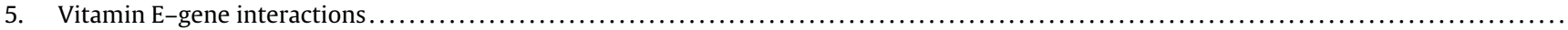

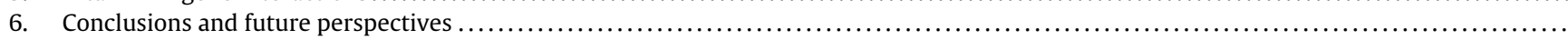

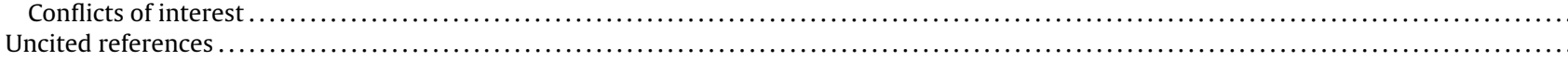

Acknowledgements.

References .

\section{Introduction}

Aging is a complex biological phenomenon often accompanied by various socio-economic changes having a great impact on the nutritional status, needs of the elderly individual and on the increased incidence of disability due to the commonly onset of some chronic diseases. Among the latter, cardiovascular and neurodegenerative diseases, diabetes, cancer, infections, are closely related to a deficiency in the nutritional status and to the presence of a chronic inflammatory condition (Mocchegiani et al., 2012). Various factors contribute to the nutritional deficiency in aging with subsequent chronic inflammation. Among them, malnutrition and the intestinal malabsorption are the more common causes of an inadequate nutritional support in elderly (Ames, 2006). The last physio-pathological conditions worsen the just precarious picture of the old body represented by the presence of chronic inflammation and oxidative stress. Under this profile, free radicals and oxidative stress have been recognized as important factors in the biology of aging and in many age-associated degenerative diseases. A time-dependent shift in the antioxidant/pro-oxidant balance, which leads to higher free radical generation, increased in oxidative stress and dysregulation of cellular function, is the basis for the free radical theory of aging (Harman, 1972; Liochev, 2013). This theory is commonly manifested with phenotypic changes and functional deterioration in later life (Harman, 2009). The changes are mainly due to the reactive oxygen species (ROS) production owing to oxidative stress leading to a damage to DNA, lipid and proteins with subsequent altered cellular homeostasis and integrity (Vina et al., 2013). As a result, the cell has an elaborate system to maintain a proper balance between the levels of free radicals and antioxidants to ensure the integrity of cellular components (Villanueva and Kross, 2012). This balance is absent in old age due to presence of high ROS production and antioxidant deficiencies (Poljsak and Milisav, 2012). It has long been postulated that supplementation with dietary antioxidant can alleviate the redox imbalance and thereby protect against the deteriorating effects of oxidative stress, progression of degenerative diseases, and aging. In this context, many micronutrients in the diet may fight oxidative stress and delay aging. Among them, Vitamin E is considered one of the most potent lipo-soluble antioxidant to delay aging and to prevent some age-related degenerative diseases (Meydani, 1995; Niki and Traber, 2012). Vitamin E is a lipid-soluble vitamin found in cell membranes and circulating lipoproteins that functions as a non-enzymatic antioxidant scavenging toxic free radicals. It refers to a group of eight compounds that possesses a similar chemical structure comprising a chromanol ring with a 16-carbon side chain and includes all isoforms of tocopherols $(\alpha, \beta, \gamma, \delta)$ and tocotrienols $(\alpha, \beta, \gamma, \delta)$ (Brigelius-Flohe and Traber, 1999). Its most active and abundant form is $\alpha$-tocopherol, which is considered the major chain-breaking antioxidant in plasma, in cell membranes and in tissues (Burton et al., 1983), capable of reacting directly with chain-carrying radicals and consequently interrupt the oxidative chain reactions (Palace et al., 1999a,b). $\alpha$-Tocopherol serves as a peroxyl radical scavenger that protects polyunsaturated fatty acids in membranes and lipoproteins (Burton et al., 1986). Apart from its antioxidant property, vitamin $\mathrm{E}$ has been reported to also enhance immune response (Pae et al., 2012) and to modulate DNA repair systems (Claycombe and Meydani, 2001) and signal transduction pathways (Azzi et al., 2004). Advances in gene chip and array technology have led to the discovery of novel Vitamin E-sensitive genes that in turn regulate signal transduction pathways. Therefore, polymorphisms in genes involved in Vitamin E tissue uptake, export, and metabolism may be important determinants for the biological activity of Vitamin E itself. Therefore, genetic determinants, environmental and lifestyle factors play important roles in the effective biological activity of Vitamin $\mathrm{E}$ in aging and in the development of age-associated diseases. Decreased food intake, a sedentary lifestyle, reduced energy expenditure in older adults together with genetic determinants and the risk factors for malabsorption in Vitamin E may further contribute to the decline of bodily functions and to the development of chronic age-related diseases. This last point is very important because conflicting results regarding the effects of Vitamin E supplementation in reducing the levels of free radical damage have been reported from human trials (Clarke et al., 2008). Some authors report Vitamin E involved in reaching longevity (Mecocci et al., 2000; Cherubini et al., 2001), whereas others report a dangerous role of Vitamin $\mathrm{E}$ affecting also the mortality (Miller et al., 2005b; Thomas, 2006). In particular, 3 meta-analyses of randomized trials found that vitamin E supplementation did not reduce mortality, implying that vitamin $\mathrm{E}$ does not lead to universal systemic benefits against the processes that lead to chronic disease (Bjelakovic et al., 2012; Abner et al., 2011; Biesalski et al., 2010). In this context, it is relevant to consider the different forms of Vitamin $\mathrm{E}$ for its possible beneficial effect on the entire health in aging taking into account that Vitamin E affects also the inflammatory/immune response (Pae et al., 2012). The current formulation of vitamin E consists primarily of $\alpha$-tocopherol, but recent research has suggested that tocotrienol, the lesser known form of vitamin E, appears superior regarding its antioxidant properties (Yoshida et al., 2003) and possesses unique biological functions unrelated to antioxidant activity not shared by tocopherol (Theriault et al., 1999; Aggarwal et al., 2010). Even among the tocopherols, particular importance is placed on the other isomers because supplementation with large doses of $\alpha$-tocopherol alone has been reported to deplete the availability of $\gamma$-tocopherol, thus denying the benefits of $\gamma$-tocopherol that are not shared by $\alpha$-tocopherol (Jiang et al., 2001). Therefore, it has been suggested that the full benefits of vitamin $\mathrm{E}$ are better achieved by supplementation with the full spectrum of vitamin $E$ isomers $(\alpha-, \beta-, \gamma-, \delta$-tocopherol) and the corresponding tocotrienols (Brigelius-Flohe et al., 2002; Wu and Meydani, 2008). Therefore, the picture of the role played by Vitamin $\mathrm{E}$ as a beneficial nutrient for the correct maintenance of many body homeostatic mechanisms is very complex especially in aging, in which the frailty of the tissues and organs may lead to the development of adverse events, especially when the use of this specific nutrient is incorrect or, at least, not well controlled at 
clinical level. This review explores what is known about the uptake and transport of Vitamin $\mathrm{E}$ and the its role played as antioxidant in inflammatory/immune response in aging and in some inflammatory age-related diseases, with also a focus on the Vitamin E-gene interactions for a correct personalized supplementation in order to achieve healthy aging and longevity.

\section{Vitamin E: intake, uptake, transport and its deficiency}

The Recommended Dietary Allowance (RDA) has established that the Vitamin E intake has to be from 7.0 to $11.1 \mathrm{mg} /$ day from conventional diets. In particular, $10 \mathrm{mg} /$ day (median $7.53 \mathrm{mg} /$ day) in men and $7.57 \mathrm{mg} /$ day (median $5.90 \mathrm{mg} /$ day) in women (Weber et al., 1997). However these recommendations for Vitamin E intake have been established without considering its possible role in enhancing important body functions and preventing chronic diseases as well as its necessity for the elderly people. Few studies report the deficiency in humans. Lipid malabsorption, deterioration of lipoprotein metabolism and genetic factors in $\alpha$-tocopherol transfer protein $(\alpha$-TTP) result in Vitamin E deficiency (Niki and Traber, 2012), which is manly associated to peripheral neuropathy and ataxia (Bromley et al., 2013; Di Donato et al., 2010). In humans, Vitamin $\mathrm{E}$ is taken up in the jejunum, the proximal part of the small intestine, where the first phase of the uptake is dependent by the amount of lipids, bile and pancreatic esterases present. Unspecific absorption occurs at the intestinal brush membrane by passive diffusion, where, together with tryglicerides, cholesterol and apolipoproteins, Vitamin E (all its isomers) is re-assembled into chylomicrons by the Golgi of the mucosa cells. The chylomicrons are then stored as secretory granula and excreted by exocytosis into the lymphatic system from where they in turn reach the blood stream. Intravascular degradation of the chylomicrons proceeds via endothelial lipoprotein lipase, a prerequisite for the hepatic uptake of tochopherols (Brigelius-Flohe and Traber, 1999) and subsequent storage in the liver, in which $\alpha$-TTP governs the hepatic uptake of Vitamin E (Burton et al., 1983). $\alpha$-TTP in the liver specifically sorts out RRR-alpha-tochopherol (a natural derivate of Vitamin E) from all incoming tocopherols for incorporation into plasma lipoproteins in exerting their antioxidant functions (Traber and Kayden, 1989). Following its systemic delivery in plasma, tissue-specific distribution and specific regulation of $\alpha$-tocopherol occur (Lagrost et al., 1998; Rigotti, 2007). From all these studies, it emerges a pivotal role played by $\alpha$-TTP in the economy of Vitamin E intake, uptake and distribution within the body. A deficiency in $\alpha$-TTP gene expression and also mutation lead to the development of a variety of diseases, such as neurodegeneration, cardiovascular diseases, diabetes and compromised immune response, which are, in turn, associated to the aging process. In the cases of $\alpha$-TTP mutation, it is relevant to note that $\alpha$-tocopherol absorption is normal, but the clearance in the removal of Vitamin E results more rapid than its supply. This phenomenon can be explained by the chylomicron form in which Vitamin E finds itself, which is more susceptible to degradation and elimination rather than the stable lipoprotein-associated form. This fact implies that in presence of $\alpha$-TTP mutation (for example in Ataxia with Vitamin E deficiency, AVED) a continuous depletion of Vitamin $E$ both at cellular and subcellular level occurs with no antioxidant defense (Azzi et al., 2002). Indeed, in the network of the cellular antioxidant defense (consisting in glutathione, protein thiols, ubiquinol) high concentrations of Vitamin E are necessary in maintaining the efficiency of this network because the cell utilizes $\alpha$-tocopherol as environmental sensor, signaling the existence of harshly oxidizing conditions that lead to $\alpha$-tochopherol consumption despite all defenses (Azzi and Stocker, 2000). In the absence of a sufficient $\alpha$-tocopherol content, cell signaling becomes altered and a plethora of deleterious phenomena emerges (Azzi, 2007), among them the more significant are the atherosclerotic lesions, via induction of CD36 mRNA expression (Ozer et al., 2006; Catalog Q2 et al., 2010; Kaga et al., 2013). Therefore, the intake, the absorption and the distribution within the body of Vitamin E is not only relevant for the antioxidant defense against ROS with a binding of Vitamin $\mathrm{E}$ to lipoproteins on cell membrane, but also for the cell signaling, in particular in immune cells (Molano and Meydani, 2012; Zingg et al., 2013) taking into account that sphingolipid metabolism could influence $\mathrm{CD} 4^{+} \mathrm{T}$ cell function (Molano et al., 2012). This fact becomes relevant in aging because of the presence of an impaired inflammatory/immune response (Franceschi et al., 2000,2007 ) and an altered sphingolipid composition in $\mathrm{CD}^{+} \mathrm{T}$ cells (Molano et al., 2012) associated with a possible diet Vitamin E deficiency due to the presence of the intestinal malabsorption (Weber et al., 1997; Niki and Traber, 2012).

\section{Vitamin E, immunity, inflammatory/immune response and aging}

As reported above, Vitamin $\mathrm{E}$ is the most effective chainbreaking, lipid-soluble antioxidant in biologic membranes of all cells. Immune cells are particularly enriched in Vitamin E because their high polyunsaturated fatty acid content puts them at especially high risk for oxidative damage (Coquette et al., 1986). Free-radical damage to immune cell membrane lipids may ultimately impair their ability to respond normally to pathogenic challenge with subsequent impaired inflammatory/immune response and development of inflammatory diseases (Meydani et al., 2005; Catalgol and Kartal-Ozer, 2010). Available evidence suggests beneficial effects of supplemental Vitamin $E$ on immune function and related diseases. Results from animal and human studies indicate that Vitamin E deficiency impairs both humoral and cell-mediated immune functions (Wu and Meydani, 2008). Taking into account the efficiency of Vitamin E in restoring cell-mediated immunity of T-cells in the aged (Meydani et al., 1990a,b; Kowdley et al., 1992; Zingg et al., 2013), several double blind, placebo controlled clinical trials tested the effect of vitamin $\mathrm{E}$ on immune system in elderly as well as in old animals (see review Pae et al., 2012). Already in the 90s, Meydani et al. (1990a) suggested that a short-term Vitamin E supplementation could improve immune responsiveness and some clinically relevant indexes of $\mathrm{T}$ cell-mediated immunity in healthy elderly. In particular, Vitamin $\mathrm{E}$ supplementation ( $800 \mathrm{mg} /$ day of $\alpha$-tocopheryl acetate) for 30 days significantly improves DTH response, ex vivo T cells proliferation and IL-2 production concomitantly with a reduction of PGE2 synthesis by PBMCs and plasma lipid peroxides (Meydani et al., 1990a). In a later paper, the same group tested the effect of lower doses of Vitamin E on free-living elderly ( $\geq 65$ years) indicating that subjects consuming $200 \mathrm{mg} /$ day of Vitamin E had a significant increase in DTH and in antibody titer to hepatitis B and to tetanus vaccine compared with placebo group and with subjects supplemented with 60-mg/day and 800-mg/day of Vitamin E (Meydani et al., 1997). It was shown that a longer (6 months) supplementation of Vitamin $\mathrm{E}$ in healthy elderly subjects (65-80 years) affected the production of IL-2, IFN- $\gamma$ (typical Th1 cytokines) and IL-4 (typical Th2 cytokine) by PBMCs after stimulation with mitogens. In particular, IL-2 and IL-4 production increased while IFN- $\gamma$ production decreased in the groups receiving Vitamin E (Pallast et al., 1999). Moreover, healthy elderly subjects receiving a diet supplementation with Vitamin $\mathrm{E}$ ( $200 \mathrm{mg} /$ daily) for 3 months showed an improvement of mitogeninduced lymphocytes proliferative response and IL-2 production, NK cell activity, chemotaxis and phagocytosis of neutrophils, and a decrease in neutrophil adherence and superoxide anion production. It is worth noting that most of these improvements were reduced to the baseline levels after 6 months by the ending of the 
268 supplementation (De la Fuente et al., 2008). From all these findings, it emerges that Vitamin $\mathrm{E}$ is an immunoregulator nutrient in elderly with an effect especially in cell-mediated and innate immunity with thus a possible role in preventing some inflammatory diseases. Such an assumption is also supported by the findings in old animals and "in vitro" models explaining also the mechanisms how the Vitamin E works. In particular, Vitamin E can enhance $\mathrm{T}$ cell-mediated function by directly influencing membrane integrity and signal transduction in T cells mainly affecting CD3/TCR complex as well as CD36 gene expression (Ozer et al., 2006) and the subsequent cascade of key activators in the signal transduction. Among them, PKC, ICAM-1, ZAP-70, LAT, Vav and nuclear factor-kappaB $(\mathrm{NF}-\mathrm{\kappa} \mathrm{B})$ (the latter at nuclear level) play a key role in activating IL2 gene into the T cells (CD4 ${ }^{+}$) (Wu and Meydani, 2008; Molano and Meydani, 2012; Zingg et al., 2013). A pre-incubation with Vitamin $E$ in purified spleen $T$ cells from young and old mice increased both cell-dividing and IL-2-producing capacity of naive T cells from old mice, with no effect on memory T cells. These results were of particular interest because they indicated, on one side an effect of Vitamin E on genes involved in cell cycle (Ccnb2, Cdc2, and Cdc6) and therefore in cell proliferation; on the other side, they pin-point that Vitamin E has a direct immune-enhancing effect via increased IL-2 production. This fact is relevant because it suggests that Vitamin E can reverse the age-associated reduction in activation-induced division on naïve $\mathrm{T}$ cells, which represent a $\mathrm{T}$ cell subset exhibiting the greatest age-related defects (Adolfsson et al., 2001). An intriguing point is the dose of Vitamin E used for in vitro supplementation (RRR-a-tocopherol at the dose of $0.02 \mathrm{lg} / \mathrm{L}$ or $46 \mathrm{lU}$ ) in enhanced IL- 2 production by purified $C D 4^{+} \mathrm{T}$ cells from aged mice (Adolfsson et al., 2001). Such a dose is equivalent to the average level measured in the plasma of humans taking a daily vitamin $\mathrm{E}$ supplement of $200 \mathrm{IU}(134 \mathrm{mg})$, a dose which is safe in humans and optimally enhances the immune response in the elderly (Pallast et al., 1999). Moreover, Vitamin E is able to reverse the age associated increase of macrophages synthesis of $\mathrm{PGE}_{2}$, a well-known potent $T$ cell suppressor and inflammatory mediator (Goodwin and Webb, 1980; Wu et al., 1998). It was also reported that PGE2, apart from being immunosuppressive, regulates the balance of activity between Th1 and Th2 subsets in favor of the latter (Phipps et al., 1991). Thus, it was speculated that, through its action on PGE $_{2}$ synthesis, Vitamin E stimulates Th1-like immune responses (Meydani et al., 1990a,b). Alternatively, Vitamin E exerts its immune enhancing effect through inhibiting COX activity without altering COX-1 or COX-2 expression at either protein or mRNA level (Jiang et al., 2000; O'Leary et al., 2004), via a possible reduction of peroxynitrite production, which is a molecule able to upregulate COX-2 activity without changing its expression (Beharka et al., 2002). At this regard, taking into account that nitric oxide (NO) increases in macrophages from old mice (Wu and Meydani, 2008), Vitamin E supplementation does not affect LPS-induced superoxide generation, but reduces the further potentiated superoxide generation in the presence of superoxide-generating agents. On the other hand, when NO and superoxide inhibitors were added to macrophages from old mice fed control diet to block generation of ONOO, COX activity was significantly reduced. These results suggest that Vitamin E reduces COX activity in old macrophages by decreasing NO production, which leads in turn to lower production of ONOO (Beharka et al., 2002). The positive effect of Vitamin $\mathrm{E}$ against ROS on $\mathrm{CD}^{+}$naïve $\mathrm{T}$ cells, comes also from data by the using of confocal microscopy. Marko et al. (2007) observed that in vitro supplementation with Vitamin E (RRR-a-tocopherol, at the dose of $0.02 \mathrm{lg} / \mathrm{L}$ or $46 \mathrm{lM}$ ) increased the percentage of aged $\mathrm{CD} 4^{+}$ $\mathrm{T}$ cells capable of forming effective immune synapses by $54 \%$ on average. An increased redistribution of ZAP-70 into the immune synapse was also seen upon Vitamin $\mathrm{E}$ in vivo supplementation in naïve $\mathrm{CD}^{+} \mathrm{T}$ cells in old mice (Marko et al., 2007). However, the mechanism of Vitamin $\mathrm{E}$ in affecting $\mathrm{T}$ cells is more complex because also involving lipid rafts on cell membrane (Catalgol and Kartal-Ozer, 2010) together with another key signaling transducer SHP-1 (Fulop et al., 2002). In old age, SHP-1 increases due to its no phosphorilation because of reduced actions of lipid rafts by ROS (Fortin et al., 2006). The enhancing of SHP-1 in old age blocks Zap-70 and LAT with subsequent negative effect in IL-2 production by IL-2 gene (Molano and Meydani, 2012). Vitamin E supplementation in old age, through its double action on CD3/TCR complex (consequently on ZAP-70 and LAT activation) and on lipid rafts by reducing ROS with subsequent low expression (20\%) of SHP1 , is able to induce a correct signaling cascade for a satisfactory IL-2 production by naïve CD $4^{+} \mathrm{T}$ cells from old mice (Molano and Meydani, 2012). From these findings, it emerges that the action of Vitamin E upon the immune system is very complex involving a wide range of signaling transducers that are the subject of continue investigations. There is a general agreement that ROS contribute to the age-related decline in T cell function, probably by damaging the lipid moieties of membranes, as well as enzymatic and structural proteins (Larbi et al., 2007; Squier, 2001; Daynes et al., 2003). Thus, the best known function of Vitamin E, as a highly lipophilic antioxidant capable of preventing the propagation of polyunsaturated fatty acid peroxidation, may provide an important mechanistic basis, by neutralizing ROS-mediated damage of membrane lipids or associated adapter proteins/kinases (Molano and Meydani, 2012), and $\mathrm{CD}^{+}$naïve $\mathrm{T}$ cells have an enhanced susceptibility to oxidative damage (Lohmiller et al., 1996). The antioxidant effect of vitamin $E$ may not be only restricted in modulating $\mathrm{CD}^{+} \mathrm{T}$ cell function, but also to its influence on the activities of several enzymes involved in signal transduction pathways especially those ones related to the inflammation and, consequently, to a correct inflammatory/immune response (Lemaire-Ewing et al., 2010). For example, Vitamin $\mathrm{E}$ ( $\alpha$-tochopherol isoform) inhibits PKC (Boscoboinik et al., 1991). This aspect is relevant taking into account that PKC is involved both in cell-mediated immune response and in cell proliferation (Baier, 2003). While, on one side, the action of PKC is fundamental in young-adult age during a possible transient inflammatory state; on the other side, in chronic inflammation such as in aging, an over-expression of PKC may lead to the recruitment of an abnormal number of inflammatory cells in the inflammatory sites through the adhesion molecules (ICAM-1) worsening the just precarious inflammatory picture of aging (Battaini and Pascale, 2005). Such a phenomenon occurs in atherosclerosis, via PKC activation (Abdala-Valencia et al., 2012), and diabetes with an action on vascular smooth muscle cells (Meier and King, 2000; Way et al., 2001) and endothelial cells (Abdala-Valencia et al., 2012). Vitamin E (especially the isomer $\alpha$-tocopherol) is able to reduce the abnormal inflammatory/immune response by monocytes decreasing significantly the superoxide anion release (Tasinato et al., 1995; Wigg et al., 2004) and down regulating the gene expression of extracellular MAP-kinase (ERK 1/2), p38 and NF-кB (Ekstrand-Hammarstrom et al., 2007). As a consequence, the production of pro-inflammatory cytokines (IL-1 $\beta$ ) and the expression of adhesion molecules (ICAM1 ), via an inhibition of the 5 lipoxygenase pathway, is reduced (Devaraj and Jialal, 1999; Kato et al., 2011). Alternatively, Vitamin E may act as "Vitamin E receptor" responsible for transducing its activities (Molano and Meydani, 2012). Such an assumption is supported by the some structural similarities of $\alpha$-tocopherol to the thiazolidinediones, which are known as PPAR $\gamma$ agonists acting via PPAR $\gamma$ receptor (Gray et al., 2011). A recent study has found that the tocopherols induced the adiponectin expression via a PPAR $\gamma$ receptor-dependent mechanism. But this effect of Vitamin $\mathrm{E}$ is indirect via the induction of 15-deoxy-Delta12,14-prostaglandin J2, an endogenous PPAR $\gamma$ ligand (Landrier et al., 2009). Therefore, it is possible that some effects of Vitamin E could involve indirect interactions with intracellular receptors (Azzi, 2007), but further studies

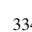

336 
are required to better elucidate this point. Therefore, Vitamin E (especially $\alpha$-tocopherol) has a direct role, via CD3/TCR complex and lipid rafts, on the immune cells acting as an antioxidant agent, whereas it has an indirect role acting on the inflammatory state, via MAPK-kinases and NF- $\kappa B$ inactivation or perhaps via PPAR $\gamma$ receptor activation, with thus anti-inflammatory properties. Therefore, a right intake and cellular content of Vitamin $\mathrm{E}$ is pivotal in aging because of impaired $\mathrm{T}$ cell function, altered inflammatory/immune response, increased oxidative stress and chronic inflammation with the risk to develop age-related inflammatory diseases (Franceschi et al., 2000). Such an assumption is strongly supported by the recent findings in centenarian subjects, who show a satisfactory Vitamin E content (Mecocci et al., 2000) coupled with a satisfactory degree of antioxidant activity, reduced inflammation (Franceschi et al., 2000), as well as good performances in inflammatory/immune response (Mocchegiani et al., 2002). As such, many age-related diseases can be escaped with the achievement of an healthy state and longevity. However, high Vitamin E intake may be harmful affecting also mortality (Miller et al., 2005b). Thus, strong caution has to be used in Vitamin E supplementation in aging and in age-related diseases. The Vitamin E-gene interactions may be an useful tool for a personalized supplementation avoiding its possible toxic effect because an interaction with other micronutrients might occur leading to an unbalance among micronutrients, as it occurs for other micronutrients (Mocchegiani et al., 2012). Moreover, an excess of Vitamin $E$ in the liver activates the pregnane $X$ receptor (PXR), a transcription factor that may lead to the expression of drug resistance genes, including cytochrome P450, glutathione S-transferase A2 and hydroxysteroid sulfotransferase (SULT2-40/41) (BrigeliusFlohe, 2003) with thus possible resistance to drugs deputed to care the chronic inflammation. As a consequence, the subsequent development of adverse events in aging can arise.

\section{Vitamin E: aging and inflammatory age-related diseases}

\subsection{Aging}

As reported above, the aging process is a physiological condition characterized by augmented ROS production and chronic inflammation that both lead to a poor resistance to oxidative stress provoked by internal antigenic insults and external noxae. Moreover, the inflammatory/immune response is impaired and the old organism is unable to adequately respond to viruses and bacteria. As a consequence, many inflammatory diseases can arise with a possible final result of mortality. One of the main cause of the reduced capacity to adequately respond to external noxae is the process of cellular senescence because producing an abnormal quantity of pro-inflammatory cytokines that worsen the just precarious condition of the old individual with subsequent damage of many organs and tissues as well as cell death (Campisi, 2000). In this context, the possibility to prevent the age-related diseases with antioxidants is of election and of primary importance. Vitamin $\mathrm{E}$ can be considered one of the most powerful antioxidants existing in nature and in the diet being present especially in palm oil, fruit and vegetables (Cao et al., 1998). "In vitro" models (spleen cells from old mice) have shown the antioxidant role of Vitamin $\mathrm{E}$ decreasing the prostaglandin production, an immune-suppressive product of lymphocyte proliferation (Webb et al., 1980). In Vitamin E deficient rats as well as in old rats, some structural component of RNA (fibrillar centers, dense fibrillar and granular components of nucleoli and perichromatin granules) are altered (Malatesta et al., 2003). However, the role played by Vitamin E in prolonging the life span in living organisms decreasing oxidative stress is of major interest even if contradictory findings have been found (Ernst et al., 2013). An increase in the average life span of short-lived autoimmune-prone NZB/NZW mice receiving Vitamin E supplements was reported in literature by Harman (1980). Recently, Vitamin E administration extended average and maximum life span for wild-type flies under hyperoxia (but not in normal $\mathrm{O}_{2}$ concentration) and for SOD1-deficient flies under normoxia (Bahadorani et al., 2008). Studies with Caenorhabditis elegans illustrate that Vitamin E supplementation significantly extends lifespan (Harrington and Harley, 1988). Vitamin E supplementation resulted in increased lifespan even in old mice (Navarro et al., 2005), even if high levels of Vitamin E had a negative impact or no visible effect on lifespan (Morley and Trainor, 2001; Lipman et al., 1998). Despite these contradictory results in animals, some clinical trials were carried out in old humans in order to decrease the oxidative stress and to ameliorate the immune response and the degree of inflammation. As described in Table 1, Meydani et al. (1990a) report that Vitamin E supplementation ( $\alpha$-tocopheryl acetate in soybean oil at the dose of $800 \mathrm{mg} /$ day for 30 days) in old people ( $\geq 60$ years) induces an increment of DTH response and IL-2 production, with thus a specific role in enhancing the cell-mediated immunity (as reported above in Section 3). These immune enhancing effects of Vitamin $\mathrm{E}$ was confirmed in three subsequent clinical trials in a more large number of old subjects even if no effect on humoral immunity was detected (Meydani et al., 1997, 1998; Pallast et al., 1999). In particular, it has been observed that 4 months of supplementation with 60, 200, $800 \mathrm{IU}$ Vitamin E/day did not induce any adverse effects (Meydani et al., 1998). These encouraging data on immunocompetence in elderly have not been confirmed when the effect of Vitamin E ( $200 \mathrm{mg} /$ day for 15 months) was evaluated by two biomarkers of immunocompetence [i.e. serum DHEA sulfate ester and neopterin] (van Amsterdam et al., 2005). Taking into account that Vitamin $C$ may regenerate Vitamin $\mathrm{E}$ by reducing tocopherol radicals (Chan, 1993), no effect of Vitamin E (400 IU of $\alpha$-tocopheryl acetate/day for 2 months) in elderly also occurs on oxidative DNA damage even when Vitamin C ( $500 \mathrm{mg} /$ day) is added to Vitamin E (Huang et al., 2000). The same inconsistent data are also observed in adult and old smokers treated with Vitamin $\mathrm{E}$ (at three doses 300 , $600,1200 \mathrm{IU} /$ day for 3 weeks) (Patrignani et al., 2000). An harmful effect in elderly was observed with even a lower dose $(50 \mathrm{mg} /$ day for 1 year) (ATBC study) (Hemila and Kaprio, 2009, 2011). No effect on immunocompetence (DHT response) occurs in elderly also with the use of Vitamin E ( $288 \mathrm{mg} /$ day) plus Vitamin C ( $375 \mathrm{mg} /$ day) for 10 weeks (Wolvers et al., 2006). Clinical trial with Vitamin E (400 IU/day) plus Vitamin C (500 mg/day) was performed in elderly in order to prevent endothelial dysfunction (Wray et al., 2012), but with inconsistent data. Recently, using meta-analysis, an exhaustive review reports that Vitamin E supplementation in elderly can be dangerous because it increases the rate of mortality especially when high doses are used (Bjelakovic et al., 2012). This evidence seems a paradox taking into account that two papers report that a satisfactory content of Vitamin E ( $\alpha$-tocopherol) in the plasma is an index of longevity (Cherubini et al., 2001; Mecocci et al., 2000). By contrast, the use of tocotrienols in elderly seems to give more satisfactory results. A mixture of tocotrienols and $\alpha$-tocopherol, named tocotrienol rich fraction (TRF) ( $160 \mathrm{mg} /$ day for six months containing $74 \%$ tocotrienols and $26 \%$ tocopherol), is able to induce an improvement of plasma cholesterol, AGE and vitamin levels as well as a reduction of the protein damage indicating a restoration of the redox balance after TRF supplementation, particularly in older individuals (Chin et al., 2011). Moreover, TRF supplementation is also beneficial in elderly by reducing DNA damage as shown by a reduction in urinary 8-OHdG (Chin et al., 2008). From all these data, it emerges that Vitamin E supplementation (especially as a mixture of tocopherol and tocotrienol) in elderly might be more beneficial than $\alpha$-tocopherol alone in order to reduce the inflammation and the oxidative stress but with strong caution because high doses of TRF may also increase all-causes of mortality (Miller, 
Table 1

Main studies on the effect of Vitamin E supplementation in aging (animals and humans).

\begin{tabular}{|c|c|c|c|c|}
\hline Models & $N$ & Intervention & Findings & Reference \\
\hline \multicolumn{5}{|l|}{ Animals } \\
\hline C. elegans & 24 & $100 \mu \mathrm{g} / \mathrm{mL}$ of $\alpha$-tocopherol & Prolonged survival +3 days & Harrington and Harley (1988) \\
\hline C. elegans & 24 & $200 \mu \mathrm{g} / \mathrm{mL}$ of $\alpha$-tocopherol & Prolonged survival +7 days & Harrington and Harley (1988) \\
\hline C. elegans & 24 & $400 \mu \mathrm{g} / \mathrm{mL}$ of $\alpha$-tocopherol & Prolonged survival +2 days & Harrington and Harley (1988) \\
\hline D. melanogaster & 900 & $20 \mu \mathrm{g} / \mathrm{mL}$ of $\alpha$-tocopherol & Prolonged survival +13 days & Zou et al. (2007) \\
\hline D. melanogaster & 600 & $\begin{array}{l}0.005,0.05,0.5,5,25 \mathrm{IU} / \mathrm{mL} \text { of } \\
\alpha \text {-tocopherol }\end{array}$ & $\begin{array}{l}\text { Prolonged survival +8 days } \\
\text { only under hypoxia }\end{array}$ & Bahadorani et al. (2008) \\
\hline Old mice & 87 & $\begin{array}{l}5000 \mu \mathrm{g} / \mathrm{g} \\
\text { dl-RRR- } \alpha \text {-tocopherol }\end{array}$ & Prolonged survival +140 days & Navarro et al. (2005) \\
\hline Old mice & 153 & $470 \mathrm{ppm}$ of $\alpha$-tocopherol & No effect & Lipman et al. (1998) \\
\hline Mice from the birth & 400 & $\begin{array}{l}20 / 400 / 4000 \mu \mathrm{g} / \mathrm{g} \text { of } \\
\alpha \text {-tocopherol }\end{array}$ & No effect & Morley and Trainor (2001) \\
\hline \multicolumn{5}{|l|}{ Humans } \\
\hline Healthy elderly $\geq 60$ years & 18 & $\begin{array}{l}800 \mathrm{mg} / \text { day of } \alpha \text {-tocopherol for } \\
30 \text { days }\end{array}$ & $\begin{array}{l}\text { Increase IL-2 production } \\
\text { Increase DHT response } \\
\text { Increase ConA stimulation } \\
\text { Decrease PGE2 and plasma } \\
\text { lipid peroxide concentrations }\end{array}$ & $\begin{array}{l}\text { Meydani } \\
\text { etal. } \\
\text { (1990a) }\end{array}$ \\
\hline $\begin{array}{l}\text { Free living healthy elderly } \\
\geq 65 \text { years }\end{array}$ & $20 / 20 / 20=60$ & $\begin{array}{l}60 / 200 / 800 \mathrm{mg} / \text { day of of } \\
\alpha \text {-tocopherol for } 235 \text { days }\end{array}$ & $\begin{array}{l}\text { Increase IL-2 production and } \\
\text { DTH response for all doses } \\
\text { used. No effect on humoral } \\
\text { immunity }\end{array}$ & Meydani et al. (1997) \\
\hline $\begin{array}{l}\text { Free living elderly 65-80 } \\
\text { years }\end{array}$ & $54 / 53=107$ & $\begin{array}{l}50 / 100 \mathrm{mg} / \text { day of of } \\
\alpha \text {-tocopherol for } 6 \text { months }\end{array}$ & $\begin{array}{l}\text { Increase IL- } 2 \text { production and } \\
\text { DHT response }\end{array}$ & Pallast et al. (1999) \\
\hline Healthy elderly $\geq 60$ years & 50 & $\begin{array}{l}50 \mathrm{mg} / \text { day of } \alpha \text {-tocopherol for } \\
15 \text { months }\end{array}$ & $\begin{array}{l}\text { No effect on serum DHEA and } \\
\text { neopterin }\end{array}$ & van Amsterdam et al. (2005) \\
\hline $\begin{array}{l}\text { Adult-old non smokers } \\
50-70 \text { years }\end{array}$ & 184 & $\begin{array}{l}400 \mathrm{IU} \text { of } \alpha \text {-tocopheryl } \\
\text { acetate/day plus } 500 \mathrm{mg} / \text { day of } \\
\text { Vit.C for } 2 \text { months }\end{array}$ & $\begin{array}{l}\text { No effect on oxidative DNA } \\
\text { damage }\end{array}$ & Huang et al. (2000) \\
\hline $\begin{array}{l}\text { Adult-old smokers 50-70 } \\
\text { years }\end{array}$ & $46 / 46 / 46$ & $\begin{array}{l}300 / 600 / 1200 \mathrm{IU} / \text { day for } 3 \\
\text { weeks of } \alpha \text {-tocopherol }\end{array}$ & $\begin{array}{l}\text { No effects on lipid peroxidation } \\
\text { and thromboxane biosynthesis }\end{array}$ & Patrignani et al. (2000) \\
\hline $\begin{array}{l}\text { Adult-old smokers 50-70 } \\
\text { years (ATBC study) }\end{array}$ & 21,657 & $\begin{array}{l}50 \mathrm{mg} / \text { day of of } \alpha \text {-tocopherol } \\
\text { for } 6 \text { years }\end{array}$ & $\begin{array}{l}\text { No effect on the risk of } \\
\text { pneumonia with also an } \\
\text { harmful effects }\end{array}$ & Hemila and Kaprio $(2009,2011)$ \\
\hline $\begin{array}{l}\text { Adult-old subjects } 40-80 \\
\text { years }\end{array}$ & 138 & $\begin{array}{l}288 \mathrm{mg} / \text { day of } \alpha \text {-tocopherol } \\
\text { plus Vitamin C ( } 375 \mathrm{mg} / \text { day) } \\
\text { for } 10 \text { weeks }\end{array}$ & No effect on DHT response & Wolvers et al. (2006) \\
\hline Healthy elderly 70 years & 45 & $\begin{array}{l}400 \mathrm{IU} / \text { day of } \alpha \text {-tocopherol and } \\
\text { Vitamin C ( } 500 \mathrm{mg} / \text { day) for } 1 \\
\text { week }\end{array}$ & $\begin{array}{l}\text { No effects on endothelial } \\
\text { dysfunctions }\end{array}$ & Wray et al. (2012) \\
\hline $\begin{array}{l}\text { Adult-old healthy } \\
\text { individuals }\end{array}$ & 62 & $\begin{array}{l}160 \mathrm{mg} / \text { day of tocotrienol rich } \\
\text { fraction (TRF) for six months }\end{array}$ & $\begin{array}{l}\text { Reduction of DNA damage and } \\
\text { 8-OHdG levels }\end{array}$ & Chin et al. $(2008,2011)$ \\
\hline Healthy elderly $\geq 70$ years & 26 & $\begin{array}{l}200 \mathrm{mg} / \text { day of } \alpha \text {-tocopherol for } \\
28 \text { days }\end{array}$ & $\begin{array}{l}\text { Increased IL-2 production } \\
\text { Increased NK cell activity } \\
\text { Increased neutrophil, } \\
\text { chemotaxis and phagocytosis } \\
\text { Increased mitogen } \\
\text { responsivness }\end{array}$ & $\begin{array}{l}\text { De } \\
\text { la } \\
\text { Fuente } \\
\text { etal. } \\
\text { (2008) }\end{array}$ \\
\hline $\begin{array}{l}\text { Nursing home resident } \\
\geq 65 \text { years }\end{array}$ & 47 & $\begin{array}{l}200 \mathrm{IU} / \text { day of } \alpha \text {-tocopherol for } \\
1 \text { year }\end{array}$ & $\begin{array}{l}\text { Decreased pro-inflammatory } \\
\text { cytokines (TNF- } \alpha, \text { IL-1 } \beta \text {, IL-6) }\end{array}$ & Belisle et al. (2008) \\
\hline
\end{tabular}

2005b). Anyway, the data available are inconclusive and strongly contradictory perhaps due to the influence of Vitamin $\mathrm{E}$ on some genes (Rimbach et al., 2010) that in turn may negatively affect the antioxidant and immune response especially in condition of chronic oxidative stress, such as in aging and in some degenerative age-related diseases.

\subsection{Infections}

The immunostimulatory effect of vitamin $\mathrm{E}$ has been shown to be associated with resistance to infections. Most of the animal studies that investigated the effect of Vitamin $\mathrm{E}$ on infectious diseases reported a protective effect despite the variations in the dose and duration of the supplementation, infectious organisms involved, and route of administration (Han and Meydani, 2000a; Han et al., 2000). Vitamin E supplementation in old mice resulted in significantly lower viral titer and preserved antioxidant nutrient status following influenza virus infection (Hayek et al., 1997). This protective effect of vitamin E against influenza infection seems to be due to an enhancement of Th1 response, increased IL-2 and IFN$\gamma$ production and NK cell activity as well as an influence on $\mathrm{PGE}_{2}$ synthesis, which plays in turn a key role in Th1 response and in the regulation of pro-inflammatory cytokines (Han et al., 2000). At this regard, two relevant transcriptional factors (NF- $\kappa \mathrm{B}$ and AP-1 involved in the transcription of pro-inflammatory cytokines) are also down-regulated by Vitamin E (Suzuki and Packer, 1993). Despite of these encouraging findings in old mice, few investigators have directly examined this role on host's resistance to infection in the elderly, reporting contrasting results, maybe due to various confounding factors, such as difference in health/lifestyle conditions of participants and intervention protocols (Pae et al., 2012) (Table 2). A double-blind placebo-controlled trial addressing the effect of one year supplementation with $200 \mathrm{mg} /$ day of Vitamin E on respiratory infections in $65+$ years elderly nursing home resident 
Table 2

Main studies on the effect of Vitamin E supplementation in infections (animals and humans).

\begin{tabular}{|c|c|c|c|c|}
\hline Subjects & $N$ & Intervention & Findings & Reference \\
\hline \multicolumn{5}{|l|}{ Animals } \\
\hline Old C57BL/6NIA mice 22 months & 40 & $500 \mathrm{ppm}$ of $\alpha$-tocopherol for 6 weeks & $\begin{array}{l}\text { Enhancement of influenza viral } \\
\text { clearance via a better Th1 response }\end{array}$ & Hayek et al. (1997) \\
\hline \multicolumn{5}{|l|}{ Humans } \\
\hline Elderly nursing home $\geq 65$ years & 617 & $\begin{array}{l}200 \mathrm{IU} / \text { day of } \alpha \text {-tocopherol for } 6 \\
\text { months }\end{array}$ & $\begin{array}{l}\text { Increased Th1 response and IL-2, IFN- } \gamma \\
\text { production coupled with reduced } \\
\text { incidence of common cold }\end{array}$ & Meydani et al. (2004) \\
\hline $\begin{array}{l}\text { Adult-old smoker hospitalized } \\
\text { subjects } 50-70 \text { years (ATBC study) }\end{array}$ & 29,133 & $\begin{array}{l}50 \mathrm{mg} / \text { day of } \alpha \text {-tocopherol }+20 \mathrm{mg} / \text { day } \\
\text { of } \beta \text {-caroten for } 6 \text { years }\end{array}$ & $\begin{array}{l}\text { Reduced incidence of pneumonia and } \\
\text { common cold }\end{array}$ & Hemila et al. (2004) \\
\hline $\begin{array}{l}\text { Old non-institutionalized individuals } \\
\geq 60 \text { years }\end{array}$ & 652 & $200 \mathrm{mg} /$ day of $\alpha$-tocopherol for 2 years & $\begin{array}{l}\text { No effect on respiratory tract infections } \\
\text { with adverse effects on illness severity }\end{array}$ & Graat et al. (2002) \\
\hline
\end{tabular}

showed that Vitamin E did not have a significant effect on lower respiratory tract infections. However, the authors found a protective effect of Vitamin E supplementation on upper respiratory tract infections in elderly, particularly the common cold suggesting an immune-stimulatory effect of Vitamin E (Th1 response, IL-2, IFN- $\gamma$ ) (Meydani et al., 2004). The Alpha-Tocopherol Beta-Carotene Cancer Prevention (ATBC) study tested the effect of a small dose $(50 \mathrm{mg} /$ day) of Vitamin $\mathrm{E}$ in combination with $20 \mathrm{mg} /$ day of $\beta$ carotene and showed limited or no effect, or even a negative effect of Vitamin E on pneumonia and common cold because depending on the age, smoking history, residence, exercise, and other factors (Hemila and Kaprio, 2004; Hemila et al., 2004). Moreover, Vitamin E may increase tuberculosis risk in heavy old smokers (Hemila and Kaprio, 2008). Finally, a double-blind trial in a cohort of Dutch well-nourished non institutionalized elderly individuals reported that neither daily multivitamin-mineral supplementation at physiological dose nor $200 \mathrm{mg}$ of Vitamin E showed a favorable effect on incidence and severity of acute respiratory tract infections with some adverse effects, such as a worsening of the illness severity (Graat et al., 2002). Taken together, all these data are contradictory even if they seem to suggest an immune-enhancing effect of Vitamin E in elderly. Further studies are needed. In particular, the evaluation of the influence of Vitamin $\mathrm{E}$ on some genes related to inflammatory/immune response may help to discern these contradictions.

\subsection{Atherosclerosis and cardiovascular diseases}

Cardiovascular diseases (CVD) is the major cause of morbidity and mortality in developed countries. It is a multi-factorial disease in which the presence of high levels of lipids in the circulation is the major contributing factor. The inflammation of the coronary artery associated with oxidative stress, accumulation of lipids and oxidation of LDL, leads to the formation of arterial lesions known as atheroma (Singal et al., 1998). In addition, high levels of plasma lipids lead to endothelium activation and increased adhesion of immune cells to the endothelium, which in turn results in endothelium dysfunction. When the atherosclerotic lesions rupture, several chemotactic factors are released by macrophages, resulting in platelet aggregation and thrombosis of the coronary artery and heart attack (Slevin et al., 2009). The reduction of oxidative stress and inhibition of LDL oxidation by Vitamin E are thought to be major actions for which it has received considerable attention as a health benefit in reducing the risk of CVD. Vitamin E in LDL particles acts as a chain-breaking antioxidant and prevents lipid peroxidation of polyunsaturated fatty acids and modification of proteins in LDL by reactive oxygen species (ROS) (Carr et al., 2000; Abdala-Valencia et al., 2012). Moreover, the Vitamin E content of LDL particles increases LDL resistance to oxidation and decreases their uptake by macrophages with subsequent low production of chemotactic factors (ICAM-1, MCP-1 and IL-8) toward human arterial lesions and less platelet aggregation (Iuliano et al., 2000). The latter phenomenon by Vitamin E occurs via inhibition of thromboxane by COX2 (Chen et al., 1998). "In vitro" studies, using human endothelial cell monolayers in culture, have shown that Vitamin E (especially $\alpha$-tocopherol), at the concentration that is achievable in plasma (40-60 $\mu \mathrm{M})$ corresponding to $400-800 \mathrm{IU} /$ day, resulted in the inhibition of LDL- and IL- $1 \beta$-induced monocyte adhesion to the endothelial cell monolayer, via decreased expression of adhesion molecules ICAM-1, VCAM-1, E-Selectin, MCP-1, and suppression of IL-6 and IL-8 production as well as PKC induction (Abdala-Valencia et al., 2012). On the contrary, the production of prostacycline $\left(\mathrm{PGI}_{2}\right)$ with vasodilatory and platelet anti-aggregatory properties increases (Martin et al., 1997; Wu et al., 1999). The protective effect of Vitamin $\mathrm{E}$ has been also demonstrated in animal models, such as in hypercholesterolemic NZW rabbits. Vitamin E (at the concentration of $1000 \mathrm{IU} / \mathrm{kg}$ in the diet for 4 weeks) inhibited both the accumulation of macrophages in the aortas and VCAM- 1 expression by endothelial cells when compared to the aortas of no supplemented rabbits (control) (Fruebis et al., 1999). A reduction of aorta smooth muscle proliferation in hypercolestolemic rabbits supplemented with Vitamin E also occurs (Aytan et al., 2008), via a possible decreased PKC production (Sirikci et al., 1996; Abdala-Valencia et al., 2012). These observations in animal models support the concept that a down-regulation of the adhesion molecule expression, a suppression of monocyte/macrophage activation, and the inhibition of the smooth muscle proliferation by Vitamin $\mathrm{E}$ are some of the potential mechanisms by which Vitamin E may suppress the development of atherosclerosis with subsequent risk of CVD. The suppressive effect of supplemental levels of vitamin E $(2000 \mathrm{IU} / \mathrm{kg}$ diet) on atherosclerosis has also been demonstrated in other animal models of atherosclerosis, such a ApoE null mice (Pratico et al., 1998) and LDL-receptor-deficient mice (Cyrus, 2003). In humans, a lot of clinical trials were carried out in order to prevent CVD risk in elderly and in old smokers, some of which have reported a clear association between the reduction in the relative risk of CVD with high intake or supplementation of Vitamin E, whereas others have shown no association. The more significant studies (Table 3) have shown that a long term ( 7 years in adult men and women) of Vitamin E supplementation reduced the risk of CVD and it was associated with a lower mortality rate from CVD (Rimm et al., 1993; Stampfer et al., 1993). The reduced relative risk of death from heart disease has been reported also in elderly subjects supplemented with Vitamin E (EPESE study) (Losonczy et al., 1996). Several other studies have shown a protective effect of synthetic Vitamin $E$ $(136 \mathrm{mg} /$ day for 6 years) against ischemic heart disease mortality in old smokers (ASAP study) (Salonen et al., 2000, 2003). Supplementation with 400 or $800 \mathrm{IU} /$ day of natural Vitamin E substantially reduced the rate of nonfatal myocardial infarction (MI) after 1 year of supplementation (Stephens et al., 1996 - CHAOS study). In contrast, two recent studies (GISSI and HOPE trials) (GISSI-Prevention Investigators, Marchioli et al., 2006; The Heart Outcomes 
Table 3

Main studies on the effect of Vitamin E supplementation in CVD (animals and humans).

\begin{tabular}{|c|c|c|c|c|}
\hline Subjects & $N$ & Intervention & Findings & Reference \\
\hline \multicolumn{5}{|l|}{ Animals } \\
\hline Hypercholesterolemic NZW rabbits & 8 & $\begin{array}{l}1000 \mathrm{IU} / \mathrm{kg} \text { of } \alpha \text {-tocopherol in the } \\
\text { diet for } 4 \text { weeks }\end{array}$ & $\begin{array}{l}\text { Inhibition of the accumulation of } \\
\text { macrophages in the aortas } \\
\text { decreased VCAM- } 1 \text { expression by } \\
\text { endothelial cells }\end{array}$ & Fruebis et al. (1999) \\
\hline Hypercholesterolemic rabbits & 24 & $\begin{array}{l}\text { injections of } 50 \mathrm{mg} / \mathrm{kg} \text { of } \\
\alpha \text {-tocopherol intramuscularly/day } \\
\text { for } 8 \text { weeks }\end{array}$ & $\begin{array}{l}\text { Reduction of aorta smooth muscle } \\
\text { proliferation via decreased PKC } \\
\text { production }\end{array}$ & Sirikci et al. (1996) \\
\hline $\mathrm{ApoE}^{-1-}$ mice & 11 & $\begin{array}{l}2000 \mathrm{IU} / \mathrm{kg} \text { in the diet of } \\
\alpha \text {-tocopherol for } 16 \text { weeks }\end{array}$ & $\begin{array}{l}\text { Decreased lipid peroxidation and } \\
\text { reduced aortic lesion areas and } \\
\text { iPF2alpha-VI levels in the arterial } \\
\text { wall }\end{array}$ & Pratico et al. (1998) \\
\hline $\begin{array}{l}\text { Low-density lipoprotein } \\
\text { receptor-deficient mice (LDLR KO) }\end{array}$ & 42 & $\begin{array}{l}2 \mathrm{IU} / \mathrm{g} \text { diet of } \alpha \text {-tocopherol for } 3 \\
\text { months }\end{array}$ & $\begin{array}{l}\text { Decreased 8,12-iso-isoprostane } \\
\text { (iP)F(2alpha)-VI and monocyte } \\
\text { chemoattractant protein-1 levels }\end{array}$ & Cyrus et al. (2003) \\
\hline \multicolumn{5}{|l|}{ Humans } \\
\hline $\begin{array}{l}\text { Adult-old healthy individuals } \\
45-75 \text { years }\end{array}$ & 39,910 & $\begin{array}{l}100 \mathrm{IU} \text { of } \alpha \text {-tocopherol/day for two } \\
\text { years }\end{array}$ & Decreased risk of CVD & Rimm et al. (1993) \\
\hline $\begin{array}{l}\text { Healthy elderly } 70-75 \text { years } \\
\text { (EPESE study) }\end{array}$ & 11,178 & $\begin{array}{l}30 \mathrm{IU} \text { of } \alpha \text {-tocopherol/day for 2-6 } \\
\text { years }\end{array}$ & $\begin{array}{l}\text { Decreased mortality for coronary } \\
\text { heart disease }\end{array}$ & Losonczy et al. (1996) \\
\hline $\begin{array}{l}\text { Adult-old smokers } 45-70 \text { years } \\
\text { (ASAP study) }\end{array}$ & 520 & $\begin{array}{l}136 \mathrm{IU} \text { of synthetic } \\
\alpha \text {-tocopherol/day for } 6 \text { years }\end{array}$ & $\begin{array}{l}\text { Prevention of atherosclerotic } \\
\text { events, ischemic heart disease } \\
\text { mortality }\end{array}$ & Salonen et al. $(2000,2003)$ \\
\hline $\begin{array}{l}\text { Adult-old patients with } \\
\text { established ischemic heart disease } \\
50-70 \text { years (CHAOS Study) }\end{array}$ & $546 / 489$ (total 1035) & $\begin{array}{l}800 / 400 \text { IU of } \alpha \text {-tocopherol/day for } \\
510 \text { days }\end{array}$ & $\begin{array}{l}\text { Reduction of the rate of non fatal } \\
\text { myocardial infarction }\end{array}$ & Stephens et al. (1996) \\
\hline $\begin{array}{l}\text { Adult-old post infarction patients } \\
50-75 \text { years (GISSI study) }\end{array}$ & 4213 & $\begin{array}{l}300 \mathrm{mg} \text { of synthetic } \\
\alpha \text {-tocopherol/day for } 3.5 \text { years }\end{array}$ & $\begin{array}{l}\text { Risk of development of congestive } \\
\text { heart failure by Vitamin E }\end{array}$ & Marchioli et al. (2006) \\
\hline $\begin{array}{l}\text { Adult and old Patients with just } \\
\text { cardiovascular disease or diabetes } \\
\geq 55 \text { years and older (HOPE Study) }\end{array}$ & 4761 & $\begin{array}{l}400 \mathrm{IU} \text { of Vitamin } \mathrm{E} \text { daily from } \\
\text { natural sources for } 4.5 \text { years }\end{array}$ & $\begin{array}{l}\text { No effects on primary } \\
\text { cardiovascular outcomes (death, } \\
\text { nonfatal myocardial infarction, } \\
\text { congestive heart failure, stroke) }\end{array}$ & Yusuf et al. (2000) \\
\hline $\begin{array}{l}\text { Adult-old healthy subjects } 40-78 \\
\text { years }\end{array}$ & 64 & $\begin{array}{l}160 \mathrm{mg} / \text { day of tocotrienol for } 6 \\
\text { months }\end{array}$ & $\begin{array}{l}\text { Reduction of DNA damage and } \\
\text { urinary } 8-\mathrm{OHdG}\end{array}$ & Chin et al. (2008) \\
\hline
\end{tabular}

Prevention Evaluation Study, Yusuf et al., 2000) reported that the Vitamin E treatment in CVD patients had no effect on reducing the primary endpoints, which included death, nonfatal myocardial infarction, congestive heart failure, stroke. The genetic background, type and dose of vitamin $\mathrm{E}$ and dietary habit and lifestyle of studied subjects might have contributed to the differential results in these studies. Therefore, the effect of vitamin E alone in clinical trial in CVD is inconclusive. The association of Vitamin E with other micronutrients may be useful in preventing risk of CVD, but also in this case the data are unconvincing. An interesting aspect is however the effect of tocotrienols (TriE) in preventing atherosclerosis and CVD risk in elderly people (Chin et al., 2008) taking into account that tocotrienols reduce plasma cholesterol levels (Qureshi et al., 1991, 2001) as well as other non-lipid related risk factors (for example, platelet adhesion/aggregation) for CVD by means of the similar biochemical mechanisms of tocopherols, especially via inhibition of thromboxane and cyclooxygenase gene expression and production (Theriault et al., 1999). Anyway, the Vitamin E-gene interaction may be an useful tool for the success of the Vitamin E supplementation in preventing atherosclerosis and the subsequent CVD risks in elderly and in adult-old smokers.

\subsection{Cancer}

With regard to cancer, Vitamin E family ( $\alpha-, \beta-, \gamma-, \delta$-tocopherols and the corresponding tocotrienols) was studied in "in vitro" and "in vivo" models in preventing cancer. Tocotrienols and tocopherols show some homology in their molecular structures. The four tocotrienols share a similar chromanol moiety with their corresponding tocopherols. While tocopherol has a saturated phytyl side-chain, tocotrienol has an unsaturated prenylated sidechain. Despite of this difference, both tocopherols and tocotrienols belonging to Vitamin E family have an antioxidant activity (KamalEldin and Appelqvist, 1996). In the field of cancer chemotherapy, tocotrienols have been shown to display better anti-tumor activity than $\alpha$-tocopherol (Catalgol et al., 2011). However, tocotrienols has had poor attention by the scientific community because scarcely present in the diet (only in certain vegetable oils, palm oil and rice bran oil) whereas tocopherols are more present in a great variety of common vegetables, oils and nuts (Bartłomiej et al., 2012). However, the growth inhibition of human, mouse, and rat tumor cell lines when exposed to tocotrienol has been reported (Nesaretnam et al., 1995). Particularly, tocotrienols, both as a tocotrienol-rich fraction (TRF) or individual fractions, inhibit the growth of human breast cancer cells in culture irrespectively of estrogen receptor (ER) status (Nesaretnam et al., 1998). The inhibitory effect on cell growth was more pronounced with $\gamma$-and $\delta$-tocotrienol (Viola et al., 2012). This independent ER status with tocotrienol has great potential for growth suppression of hormoneresponsive breast cancer cells that have become resistant to growth inhibition by antiestrogens (i.e. tamoxifen) (Nesaretnam et al., 1998). The anticancer effect of $\delta$-tocotrienol was also confirmed in not hormone-responsive breast cancer cells, such as HER-2/neuoverexpressing human SKBR3 and murine TUBO breast cancer cells. $\delta$-tocotrienol induced apoptosis of SKBR3 cells associated with mitochondrial dysfunction, energy failure, and unbalanced activity of stress/survival MAPKs, namely p38 and ERK1/2 pathways (Pierpaoli et al., 2010). The anticancer effect in increased apoptosis and in senescent-like growth arrest markers (p53, p21, p16) of cancer cells occurs also in HER-2/neu transgenic mice treated with $90 \%$ $\delta$-Tocotrienol and 10\% $\gamma$-Tocotrienol (Pierpaoli et al., 2013). These interesting data show a clear effect of tocotrienols in the prevention of cancer, but they are still in infancy for a precise anticancer role of $\delta$-, $\gamma$-tocotrienols and their transferring in humans. Further studies 
Table 4

Main studies on the effect of Vitamin E supplementation in cancer (animals and humans).

\begin{tabular}{|c|c|c|c|c|}
\hline Subjects & $N$ & Intervention & Findings & Reference \\
\hline $\begin{array}{l}\text { Animals } \\
\text { Mouse mammarian cancer } \\
\text { model (HER-2/neu transgenic } \\
\text { mice) }\end{array}$ & 8 & $\begin{array}{l}\text { Annatto tocotrienol ( } 90 \% \\
\delta \text {-tocotrienol plus } 10 \% \\
\gamma \text {-tocotrienol) for } 8 \text { weeks }\end{array}$ & $\begin{array}{l}\text { Delayed development of mammary } \\
\text { tumors. } \\
\text { Reduced number and size of mammary } \\
\text { tumor masses and those of lung metastases } \\
\text { Increased apoptosis and senescent-like } \\
\text { growth arrest of tumor cells in mammary } \\
\text { glands }\end{array}$ & Pierpaoli et al. (2013) \\
\hline
\end{tabular}

A/J mice with tumor induced by 4 -(methylnitrosamino)-1(3-pyridyl)-1-butanone plus benzo[a]pyrene

$0.3 \% \gamma$-tocopherol-rich mixture $(\gamma$-TmT) for 19 weeks

Murine of human xenograft tumor models

MexTAg transgenic mouse model for mesothelioma

Murine prostate cancer model (TRAMP Mice)

Humans

Old smokers $\geq 60$ years

1088

50 mice/each dose used

100,300 , or $1500 \mathrm{mg} / \mathrm{kg} /$ day by daily oral gavage of $\alpha$-tocopheryloxy acetic acid ( $\alpha$-TEA) for 28 days $1000 \mathrm{mg} / \mathrm{kg} /$ day by daily oral gavage of $\alpha$-tocopherol acetate for 1 month

$0.1 \% \gamma$-tocopherol-enriched in the diet for 1 month

$\alpha-, \beta-, \gamma-, \delta$-tocopherol at the doses

$7.73 / 0.08 / 4.44 / 0.78 \mathrm{mg} /$ day, respectively for 1 year

Adult-old smokers 50-70 years (ATBC study)

Healthy old men subjects

50-75 years (SELECT study)
29,133

35,533
$50 \mathrm{mg} /$ day of $\alpha$-tocopherol for 6-8 years

$400 \mathrm{IU} /$ day of all

rac-alpha-tocopheryl for 5.5 years
Reduction of tumor volume and weight

Enhanced apoptosis

Low levels of 8-8-OH-dG, gamma-H2AX and nitrotyrosine

Reduced microvessel density

No mortality and no clinical signs of toxicity in any of the $\alpha$-TEA doses tested

No effect on tumor progression and rate of survival

Upregulation of detoxifying Nrf2 and antioxidant enzymes (SOD, catalase, glutatione peroxidase)

Decreased lung cancer risk especially by $\alpha$-tocopherol

No reduction in the incidence of lung cancer

No prevention of prostate cancer with even an high risk to develop prostate cancer during the follow-up (7-12 years)
Liu et al. (2010)

Hahn and Akporiaye (2012)

Robinson et al. (2012)

Barve et al. (2009)

Mahabir et al. (2008)

ATBC Study (1994)

Lippman et al. (2009) and Klein et al. (2011) on the mortaliy (and indirectly on the survival) of treated HER2/neu transgenic mice as well as the pharmacokinetic of tocotrienols and the possible resistance and interactions to chemotherapic drugs are required, as shown in other mice cancer models treated with Vitamin E (Hahn and Akporiaye, 2012; Robinson et al., 2012). Anyway, future studies on the efficacy of tocotrienols in preventing tumorogenesis are strongly recommended. With regard to tocopherols, many studies were performed "in vitro" and "in vivo" animal models as well as a great number of clinical trials in humans (Table 4) for a possible anticancer effect of tocopherols. Many of these studies were conducted with $\alpha-, \gamma-, \delta$-tocopherol $(T)$ and with a mixture rich in $\gamma$-tocopherol (named $\gamma$-TmT). $\gamma$-TmT is a by-product in the distillation of vegetable oil and usually contains (per g) $130 \mathrm{mg} \alpha-\mathrm{T}$, $15 \mathrm{mg} \beta-\mathrm{T}, 568 \mathrm{mg} \gamma$-T, and $243 \mathrm{mg} \delta$-T. Some of these studies have been well summarized in a recent review showing however contradictory and inconsistent data (Yang and Suh, 2013). Young A/J mice treated with a tobacco carcinogen, 4-(methylnitrosamino)-1-(3pyridyl)-1-butanone (NNK) with subsequent development of lung cancer, a treatment with $0.3 \% \gamma-\mathrm{TmT}$ in the diet, during the entire experimental period (11 weeks), lowered the tumor multiplicity by $30 \%$. $\gamma$-TmT treatment also significantly reduced the average tumor volume and tumor burden coupled with increased apoptosis of the cancer cells without affecting apoptosis in non-tumor lung tissues. $\gamma$-TmT treatment also significantly decreased the percentage of positive cells to 8-hydroxydeoxyguanosine (8-OXOdG), a marker of the oxidative DNA damage, as well as to phospho-histone $2 \mathrm{AX}$ (c-H2AX) (from $0.51 \%$ to $0.23 \%$ ), a reflection of double-strand break-induced DNA repair. The high plasma levels of prostaglandin $\mathrm{E}_{2}\left(\mathrm{PGE}_{2}\right)$ and leukotriene $\mathrm{B}_{4}\left(\mathrm{LTB}_{4}\right)$ in tumor-bearing mice were decreased by $\gamma$-TmT treatment. The anti-angiogenic activity of dietary $\gamma$-TmT reduced microvessel density (CD31-labeled capillary clusters and blood vessels) in the peripheral area of the lung adenomas (Lu et al., 2010). These results suggest the pro-apoptotic antioxidative, anti-inflammatory and anti-angiogenic activities of $\gamma$-TmT. The same phenomena in preventing cancer development also occurred for $\gamma$-tocopherol, but not for $\alpha$-tocopherol, as shown in vitro studies of H1299 cells (Lu et al., 2010). The prevention also occurred in another animal model of prostate cancer (TRAMP mice), in which the main actors in the prevention of cancer by $\gamma$-TmT and $\gamma$-tocopherol are the reduction of the inflammation and oxidative stress (Barve et al., 2009) and the increased apoptosis of cancer cells by caspase-3 (Yang and Suh, 2013). Recently, $\alpha$-tocopheryloxy acetic acid ( $\alpha$-TEA), another derivative of Vitamin E, also suppressed the tumor growth in various murine and human xenograft tumor models coupled with no mortality and no toxicity by the different doses used of $\alpha$-TEA (Hahn and Akporiaye, 2012). By contrast, Vitamin E supplementation in the diet (as $\alpha$-tocopherol acetate $1000 \mathrm{mg} / \mathrm{kg} /$ day for $1 \mathrm{month}$ ) in MexTAg transgenic mouse model for mesothelioma has no effect on tumor progression and the rate of survival (Robinson et al., 2012). Anyway, these data in animals suggest that Vitamin $\mathrm{E}$ can prevent cancer not in all its isoforms or, at least, in their combined isoforms (Table 4), as shown in preventing lung cancer progression in human smokers by their combinations (Mahabir et al., 2008). The supplementation of $\alpha$-tocopherol alone is instead unable to prevent cancer, as shown in ATBC study in adult-old smokers (50 mg/day for 6-8 years) (ATBC Study, 1994). The recent Selenium and Vitamin E Cancer Prevention Trial (SELECT study), $400 \mathrm{IU}$ of all-rac- $\alpha$-tocopheryl acetate or $200 \mathrm{~g}$ selenium (from L-selenomethionine) or both, daily for an average of 5.5 years, did not prevent prostate cancer (Lippman et al., 2009). During the follow-up (for 7-12 years), subjects receiving $\alpha$-tocopheryl acetate had an high risk for developing prostate cancer (hazard ratio of 1.17) (Klein et al., 2011). Moreover, in the SELECT study, the $\alpha$ tocopherol supplement caused a $50 \%$ decrease in median plasma 
$786 \quad \gamma$-tocopherol levels (Lippman et al., 2009). One possible explanation is that high $\alpha$-tocopherol might cause a decrease in blood and tissue levels of $\gamma$-tocopherol, more effective in cancer prevention, because more efficient in trapping reactive oxygen and nitrogen species (RONS) (Ju et al., 2010; Reiter et al., 2007). Such an hypothesis is supported by the correct combination of the various isoforms of Vitamin E in preventing prostate cancer in mouse prostate cancer (TRAMP) model (Barve et al., 2009). Alternatively, the lack of cancer prevention effect by $\alpha$-tocopherol may be to the genetic characteristics of the population (Yang et al., 2013). Thus, a question arises: does Vitamin E prevent or promote cancer in humans? The Vitamin E-gene interactions may give a satisfactory answer to this question.

\subsection{Diabetes mellitus}

Diabetes mellitus (DM) is a global health problem that results in a greater risk of vascular complications, decreased quality of life, and increased mortality. DM patients suffer from metabolic alterations which affect many organs and systems, especially the cardiovascular system with the development of some cardiovascular diseases (CVD), such as infarction and stroke (Kuusisto and Laakso, 2013). DM is characterized by high plasma glucose levels, by an increase in oxygen radical formation due to glucose auto oxidation, by the glycation of both plasma and cellular proteins with the formation of advanced glycation end products (AGEs) and nitrosative stress by excessive NO release. All these phenomena have as target the blood vessel leading to endothelial dysfunction. Moreover, smoking, hypertension and hyperlipidemia enhance oxidation of lipids and their subsequent accumulation in macrophages, leading to foam cell formation and atherosclerotic plaque development, whose rupture by increased stress and inflammation has, as final result, the arising of myocardial infarction or stroke. Therefore, the influence of different antioxidants has been the subject of many studies over the years in relation to DM and CVD complications rather than to DM "in se". Due to the involvement of LDL oxidation in the pathology of atherosclerosis and CVD, Vitamin E was extensively studied in DM in order to prevent CVD risks. In streptozotocin diabetic rats Vitamin $\mathrm{E}$ (both as tocopherol and tocotrienol) prevents the development of abnormal contractility and structure and endothelial dysfunction in aorta (ADIC study) (Karasu et al., 1997) and decreases the AGEs formation (Wan Nazaimoon and Khalid, 2002; Forbes and Cooper, 2013). Moreover, a bran extract Ricetrienol (containing $\alpha$-tocopherol, and tocotrienols) prevents oxidative stress in obese diabetic KKAy mice (Kanaya et al., 2004). Several observational epidemiologic studies in humans suggest that Vitamin E supplementation might decrease the risk of developing CVD. In this context, as reported in extensive reviews (Meydani, 2001; Goldenstein et al., 2013), a lot of clinical trials with Vitamin E alone or associated with other substances, such as aspirin or ACE inhibitors, was carried out but with often inconsistent results (Table 5). In Finnish (Virtamo et al., 1998) and Italian (de Gaetano, 2001) studies, the randomized clinical trials in smokers hypertensive adult and elderly subjects, respectively, with Vitamin E supplementation $(50 \mathrm{mg} /$ day for $5-8$ years and followed until the first myocardial infarction) have shown in both studies a slight but not statistically significant decrement in the incidence of myocardial infarction. In the St. Francis Heart Study randomized clinical trial (Arad et al., 2005), supplementation of aspirin $(81 \mathrm{mg} / \mathrm{mL})$ with Vitamin E (1000 IU/day), vitamin C ( $1 \mathrm{~g} /$ day) and atorvastatin ( $20 \mathrm{mg} /$ day) for 4 years in adult and elderly subjects with coronary calcium scores $\geq 400$ did not affect the progression of calcium deposits in the coronary arteries or improve clinical symptoms. Other studies (ATIC study, Physicians Health study, Womens' Health study, VEAPS study) performed in adult and old hypertensive subjects with hyperglycemia confirmed the no effect of Vitamin E supplementation also with high doses (400-600 IU/day for 3 years) in preventing CVD complications by diabetes or by its renal complications (Hodis et al., 2002; Nanayakkara et al., 2007; Lee et al., 2005) with even an increased risk of hemorrhagic stroke (Sesso et al., 2008). Previous studies by the Gruppo Italiano per lo Studio della Sopravvivenza nell' Infarto miocardico (GISSI, 1999) and Cambridge Heart Antioxidant Study (CHAOS study) (Stephens et al., 1996) have not found any effect of Vitamin E supplementation at high doses in preventing CVD risks in hypertensive and hyperglycemic old subjects. The treatment with Vitamin E decreased the risk of developing non-fatal myocardial infarction, but increased the risk of CV death (Stephens et al., 1996). Similar results were obtained from the Heart and Outcomes Prevention Evaluation (HOPE study) (Yusuf et al., 2000), in which Vitamin E (400 mg/day for 4.5 years) supplementation was associated to angiotensin converting enzyme (ACE) inhibitor (Ramipril). The results showed that Vitamin E did not influence the risk of developing CVD with even an higher risk of heart failure (HOPE-TOO study) (Lonn et al., 2005). The Women's Angiographic Vitamin and Estrogen (WAVE study) trial showed an increased risk of developing coronary heart disease in postmenopausal women who received Vitamin E (400 IU/day for 3 years) (Waters et al., 2002). By contrast, the Secondary Prevention with Antioxidants of Cardiovascular Disease End stage Renal Disease (SPACE) study showed a beneficial effect of Vitamin E supplementation (800 IU/day for 2 years) in hemodialysis and hyperglycemic patients although the risk of mortality was not affected (Boaz et al., 2000). In conclusion, data regarding the beneficial role of Vitamin $\mathrm{E}$ in protecting against cardiovascular complications in hyperglycemia are contradictory. On the other hand, a recent paper showed that Vitamin E supplementation was not associated with a decreased risk of incident diabetes "in se" in middle-aged male smokers (Kataja-Tuomola et al., 2011). Moreover, recent data from the Action to Control Cardiovascular Risk in Diabetes Study Group (ACCORD study) (2008) and two subsequent ACCORD studies (2010a,b) assessing these strategies in type 2 diabetics raise serious doubts regarding the effectiveness and the safety of Vitamin E intervetion and its clinical goals. However, recent investigations into the polymorphic serum protein haptoglobin (Hp) indicate that Vitamin E may be beneficial in a genetically defined subgroup of diabetic patients, namely, diabetic patients of the Hp 2-2 genotype (Vardi et al., 2012). Hp is known best as a hemoglobin $(\mathrm{Hb})$ binding protein and antioxidant agent (Levy et al., 2010). Binding of free Hb by Hp changes the tertiary structure of $\mathrm{Hb}$ so that the heme group within its heme pocket is less accessible and less chemically reactive. In such a way, the $\mathrm{Hp}-\mathrm{Hb}$ complex, being very stable $\left(K_{\mathrm{d}}=10^{-15}\right)$, prevents iron loss protecting tissues from $\mathrm{Hb}$-induced oxidative damage (Asleh et al. 2003). Hp-Hb complex formation creates an unique binding site that is recognized by CD163, a receptor on circulating monocytes and macrophages in the liver protecting the kidney from the damage by $\mathrm{Hb}$. When $\mathrm{Hp}$ is altered provokes diabetic nephropathy, a complication in old diabetic patients (Bakris, 2011). Thus, taking into account that diabetic patients carrying $\mathrm{Hp} 2-2$ genotype has a benefit by Vitamin E supplementation (Vardi et al., 2012) (see below Section 5), the role played by Vitamin E-Hp gene interaction may be crucial in diabetes mellitus in preventing also CVD complications.

\subsection{Neurodegeneration}

Advanced age is the most important risk factor for the development of neurodegenerative disorders of the brain, which lead to cognitive impairment and dementia. As the number of people who live beyond the age of 60 years is constantly growing, both cognitive impairment and dementia become increasingly prevalent (Fratiglioni et al., 2000). Alzheimer's disease (AD) is the most common neurodegenerative disorder of the brain and accounts for about $50-70 \%$ of all dementia cases (Mattson, 2004). AD is usually 
Table 5

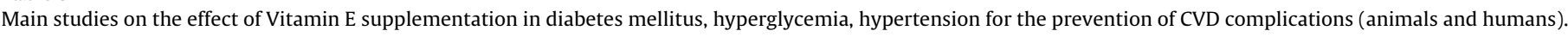

\begin{tabular}{|c|c|c|c|c|}
\hline Subjects & $N$ & Intervention & Findings & Reference \\
\hline \multirow[t]{2}{*}{$\begin{array}{l}\text { Animals } \\
\text { Streptozotocin diabetic rats } \\
\text { (ADIC study) }\end{array}$} & 10 & $\begin{array}{l}0.5 \% \text { dietary supplement of Vitamin E } \\
\text { as DL- } \alpha \text {-tocopheryl acetate for } 2 \\
\text { months }\end{array}$ & $\begin{array}{l}\text { Prevention of the development of } \\
\text { abnormal contractility and } \\
\text { structure and endothelial } \\
\text { dysfunction in aorta }\end{array}$ & Karasu et al. (1997) \\
\hline & & & Decrease AGE formation & $\begin{array}{l}\text { Wan Nazaimoon and Khalid } \\
\text { (2002) }\end{array}$ \\
\hline Obese diabetic KKAy mice & 12 & $\begin{array}{l}0.1 \% \text { of Ricetrienol (containing } \\
\alpha \text {-tocopherol, and tocotrienols) in the } \\
\text { diet for } 6 \text { weeks }\end{array}$ & $\begin{array}{l}\text { Increased urine 8-isoprostane and } \\
\text { 8-OHdG } \\
\text { Increased GPx gene expression }\end{array}$ & Kanaya et al. (2004) \\
\hline
\end{tabular}

\section{Humans}

Adult-old smoker and hypertensive subjects $50-70$ years (ATBC study) Old hypertensive female $\geq 65$ years (Collaborative Group of the Primary CVD Prevention Project)

Adult-old healthy subjects with coronary calcium scores at or above the 80th percentile $50-70$ years (St. Francis Heart Study randomized clinical trial) Adult-old healthy women with hypertension and hyperglycemia $\geq 45$ years (Women's Health Study) Adult-old subjects with hypertension hyperglycemia hypercholesterolemia 40-80 years (VEAPS study) Adult-old Subjects with hyperglycemia, hypertension $40-80$ years. GISSI-Prevenzione Investigators (Gruppo Italiano per lo Studio della Sopravvivenza nell'Infarto Miocardico) Adult-old subjects with hypertension and hyperglycemia 50-70 years (CHAOS study)

Adult-old subjects with diabetes 50-70 years (HOPE study)

Postmenopausal woman with hypertension, hyperglycemia and coronary disease $\geq 55$ years (WAVE Study)

Adult-old hemodyalis patients with previous CVD and hyperglycemia 40-75 years (SPACE study)
$27,271 \quad 50 \mathrm{mg} /$ day of $\alpha$-tocopherol for 5 years

$4495300 \mathrm{mg} /$ day of synthetic $\alpha$-tocopherol for 3.6 years

$100520 \mathrm{mg} /$ day of atorvastatin plus $1 \mathrm{~g} /$ day of Vit. C plus $1000 \mathrm{U} /$ day of $\alpha$-tocopherol for 4.5 years

$39,896 \quad 600 \mathrm{IU} /$ day of $\alpha$-tocopherol for 10 years

$177400 \mathrm{IU} /$ day of $\alpha$-tocopherol for 3 years

$11,324 \quad 300 \mathrm{mg} /$ day of synthetic $\alpha$-tocopherol for 3.5 years

$800 \mathrm{IU} /$ day of $\alpha$-tocopherol for 1 year

$400 \mathrm{IU} /$ day of $\alpha$-tocopherol for 4.5 years

$400 \mathrm{IU} /$ day of $\alpha$-tocopherol for 3 years
Slight decrement in the incidence of myocardial infarction

No effect of primary events for CVD (death, myocardial infarction, stroke)

No influence on the progression of coronary calcification

No benefit for major cardiovascular events (myocardial infarction and stroke)

No progression in reducing carotid artery-wall intima-media thickness

No effect on primary CVD endpoints (death, non-fatal myocardial infarction, and stroke)

Reduction of the rate of non-fatal myocardial infarction

No effect on cardiovascular outcomes (myocardial infarction, stroke, angina, congestive heart failure) with even the risk to develop heart failure (HOPE-TOO study)

No cardiovascular benefit on primary endpoints (non fatal myocardial infarction, stroke, death)

Reduction of composite cardiovascular disease endpoints and myocardial infarction
Virtamo et al. (1998)

de Gaetano (1999)

Arad et al. (2005)

Lee et al. (2005)

Hodis et al. (2002)

GISSI (1999)

Stephens et al. (1996)

Yusuf et al. (2000) and Lonn et al. (2005)

Waters et al. (2002)

Boaz et al. (2000)
914 diagnosed beyond the age of 65 years, although cases of familial 915 AD, which are associated with mutations in certain predisposing 916 genes (e.g. presenilin-1, presenilin-2, amyloid $\beta$ precursor protein), 917 do occur at an earlier age (Lin and Beal, 2006) with progressive 918 loss of memory (Strittmatter and Roses, 1996). The underlying pathophysiological mechanisms in the brain include the extracellular accumulation of mis-folded proteins, synaptic dysfunction, mitochondrial dysfunction, massive progressive loss of neurons by apoptosis, especially in the hippocampus and cortex, and a selective depletion of neurotransmitter systems (e.g. acetylcholine) (Leuner et al., 2007; Mattson, 2004). On the cellular level, the processes leading to neuronal death and to neurodegenerative events are caused or result in an increased formation of reactive oxygen and nitrogen species, via enhanced lipid peroxidation mainly provoked by the chronic inflammation and increased peroxynitrite production with subsequent abnormal inflammatory/immune activation (Lin and Beal, 2006). Taking into account the role played by MAP2 protein in inducing neuron plasticity (Sanchez et al., 2000), of interest is the increase in cerebellar cortex of MAP-2 mRNA levels in Vitamin E-deficient and old rats blocking the neuroplasticity of dendritic cells (Casoli et al., 2004). Consequently, antioxidant nutrients, such as tocotrienols and other members of the Vitamin E family ( $\alpha-, \gamma-, \delta$-tocopherols) are thought to be beneficial in the prevention of neurodegeneration and dementia. Epidemiological studies indicate that a high intake of Vitamin E from food sources, as well as dietary supplements, may contribute to the prevention of age-related neurodegenerative disorders (Engelhart et al., 2002; Morris et al., 2005). Such an assumption is supported by in vitro and in vivo experiments, in which all the isoforms of tocotrienols and tocopherols have been used. A tocotrienol rich fraction (TRF) isolated from palm oil significantly inhibited oxidative damage to both lipids and proteins induced by azobis (2-amidopropane)dihydrochloride (a free radical initiator) in isolated rat brain mitochondria at concentrations of $5 \mu \mathrm{mol} / \mathrm{L}$. This protection was conferred by $\alpha$-tocotrienol, and to a lesser extent by $\delta$-tocotrienol and $\gamma$-tocotrienol, and it was much more potent than $\alpha$-tocopherol (Kamat and Devasagayam, 1995; Kamat et al., 1997). In primary astrocyte cultures and in SY5Y neuronal cells, $\alpha$-tocotrienol (at the dose of $100 \mu \mathrm{mol} / \mathrm{L}$ ) protects against $\mathrm{H}_{2} \mathrm{O}_{2}$ induced cell death and apoptosis, whereas $200 \mu \mathrm{mol} / \mathrm{L}$ is toxic (Mazlan et al., 2006). This protection of $\alpha$-tocotrienol against oxidative insults was more potent than $\alpha$-tocopherol (Huebbe et al., 
Table 6

Main studies on the effect of Vitamin E supplementation in neurodegeneration (animals and humans).

\begin{tabular}{llll}
\hline Subjects & $N$ & Intervention & Findings \\
\hline $\begin{array}{l}\text { Animals } \\
\text { Male streptozoticin (STZ) treated rats }\end{array}$ & 10 & $\begin{array}{l}\text { Mixture of } \alpha-, \beta-, \gamma \text {-tocotrienol } 50 \text { or } \\
100 \mathrm{mg} / \mathrm{kg} \text { bw and } \alpha \text {-tocopherol }\end{array}$ & $\begin{array}{l}\text { Reduction in glutathione and } \\
\text { catalase } \\
\text { Reduced malonaldehyde, nitrite } \\
\text { and cholinesterase activity in the } \\
\text { brains of STZ rats. Tocotrienols are } \\
\text { more potent in preventing }\end{array}$ \\
& & & $\begin{array}{l}(100 \mathrm{mg} / \mathrm{kg} \text { bw }) \text { in the diet for } 3 \text { weeks } \\
\text { cognitive deficits caused by STZ }\end{array}$
\end{tabular}

Old rats (24 months)

Young rats (4 weeks of age)

Young rats with

intracerebroventricular injection of AF64A

Middle age rats with Vitamin E deficiency in diet

Gerbil with carotid artery occlusion

APP transgenic mice

Hypercholesterolemic Albino rabbits with Vitamin E deficiency in the diet (1-2 months old)

\section{Humans}

Alzheimer disease (AD) patients $\geq 65$ years

Old subjects with mild cognitive impairment $\geq 65$ years (Alzheimer's Disease Cooperative Study Group) AD patients $\geq 65$ years
One injection of $200 \mathrm{mg} / \mathrm{kg}$ of $\alpha$-tocopherol

10 Diet with Vitamin E deficiency for 1 month

One injection of $200 \mathrm{mg} / \mathrm{kg}$ of $\alpha$-tocopherol

$12200 \mathrm{IU} /$ day of $\alpha$-tocopherol for 2 months

11 Intravanenous administration of 50 or $100 \mathrm{mg} / \mathrm{kg}$ of $\alpha$-tocopherol

10 Injection of $200 \mathrm{mg} / \mathrm{kg}$ of $\alpha$-tocopherol

8 Intramuscularly injection of $50 \mathrm{mg} / \mathrm{kg} /$ day for 4 weeks of Vitamin E ( $\alpha$-tocopherol)

$341 \quad \alpha$-Tocopherol 2000 IU/day for 2 years

$7692000 \mathrm{IU} /$ day of $\alpha$-tocopherol for 3 years

$57800 \mathrm{IU} /$ day of $\alpha$-tocopherol for 6 months
AD patients $\geq 65$ years (Chicago Health and Aging Project)

AD patients $\geq 80$ years (Kungsholmen Project)
746

$\alpha$-Tocopherol and $\gamma$-tocopherol exclusively from food sources for 6 years

232 All isofoms of tocopherols and tocotrienols from food sources for 6 years
Improved memory retention

Reduced learning behavior

Improved water maze performance

Inhibition of lipid peroxidation Increase GSH-Px activity Reduced lipofuscin accumulation

Reduced neuronal cell death induced by ischemia Inhibition of amyloid- $\beta$ induced cell death

Decreased of brain protein carbonylation (an hallmark of AD and neurodegeneration)
Reference

Tiwari et al. (2009)

(2009)

.

Socci et al. (1995)

Ichitani et al. (1992)

Wortwein et al. (1994)

Meydani et al. (1988)

Monji et al. (1994)

Hara et al. (1990)

Behl et al. (1992)

Aytan et al. (2008)

Harmful effect with progression of the disease and worsening of cognitive performances

No effect in cognitive improvement and in the progression of AD

Lowering of the oxidative stress in some AD patients and maintaining cognitive status. In AD with no prevention of oxidative stress by Vitamin E, which is detrimental on the cognitive functions

High intake by foods of Vitamin E isoforms slowdowns the cognitive decline

The risk of developing AD progression was reduced only in association with high plasma levels of $\beta$-tocopherol. $\alpha$-tocopherol, $\beta$-tocotrienol, $\gamma$-tocotrienol have marginal effects No effect on tremor, rigidity, bradykinesia, and postural instability

No effects on neurologic and neuropsychiatric symptoms

\section{$1202000 \mathrm{IU} /$ day for 2 years}

$732000 \mathrm{IU} /$ day for 2 years

Huntington's disease $\geq 50$ years

2007). The higher protective capacity of $\alpha$-tocotrienol compared to $\alpha$-tocopherol may be mainly related to its faster cellular uptake (Saito et al., 2010). As recently reported in an exhaustive review by Frank et al. (2012), $\alpha$-tocotrienol protects Neuro2a cells against $\mathrm{H}_{2} \mathrm{O}_{2}$-induced cell death, via a reduction of collapsin response mediator protein-2 (CRMP-2), a protein involved in microtubule polarity and axon guidance, whose expression is increased in neurons in the vicinity of amyloid- $\beta$ plaques in the cerebral cortex of a mouse model of AD [APP(Swe) Tg2576 mice] (Petratos et al., 2008). This last finding suggests a role of $\alpha$-tocotrienol against oxidative damage induced by $\beta$-amyloid accumulation, as previously also shown by $\alpha$-tocopherol in $\beta$-amyloid-induced cell death in rat hippocampal cell cultures (Goodman and Mattson, 1994), PC12 cells (Behl et al., 1992) and in neuroblastoma cells after amino acid-induced toxicity (Murphy et al., 1990). These promising "in vitro" data on the protective effect of both tocotrienols and tocopherols in injured brain cells were transferred "in vivo" animal models. In rats, intracerebroventricular injection of streptozotocin causes oxidative stress in the brain coupled with cell-death leading to cognitive dysfunction by inhibiting the synthesis of ATP and acetylcoenzyme A (Tiwari et al., 2009). Daily oral gavage of a mixture of $\alpha-, \beta-, \gamma$-tocotrienol (50 or $100 \mathrm{mg} / \mathrm{kg} \mathrm{bw})$ and $\alpha$-tocopherol $(100 \mathrm{mg} / \mathrm{kg} \mathrm{bw})$ for 3 weeks attenuated the reduction in glutathione and catalase and decreased nitrite concentrations in the brains of streptozotocin-injected adult male Wistar rats (Tiwari et al., 2009). Such a mixture of Vitamin E family prevents oxidative damage and cognitive impairment (determined by Morris water maze and elevated plus maze tasks), although a trend toward a better protection by tocotrienol isoforms was observed (Tiwari et al., 2009). Anyway all the family of Vitamin $\mathrm{E}$, including tocopherols, is protective against oxidative stress (Frank et al., 2012), with an improvement on cognitive performance 
in aged animals and prevents oxidative damage in animal models of $\mathrm{AD}$. At this regard, old literature reports the beneficial effect of Vitamin E as also $\alpha$-tocopherol. Socci et al. (1995) found that aged rats treated with Vitamin $\mathrm{E}$, have greater memory retention than do placebo treated rats. In another study, Vitamin E supplementation protects against the deterioration in passive avoidance response in old rats (Ichitani et al., 1992). Vitamin E also protects against impaired water maze performance resulting from treatment with a neurotoxin $(\mathrm{AF} 64 \mathrm{~A})$ that induces oxidative stress in cholinergic neurons (Wortwein et al., 1994). Dietary Vitamin E supplementation reduces lipofuscin accumulation in the brain of middle-aged rats (Monji et al., 1994) and protects against lipid peroxidation (Meydani et al., 1988). In gerbils, Vitamin E prevents ischemic damage to neurons of the hippocampus (Hara et al., 1990). Transgenic mice over-expressing the amyloid precursor protein (APP) show accelerated age-associated brain degeneration (Hsiao, 1995). Vitamin E supplementation can delay this deterioration (Behl et al., 1992; Koppal et al., 1998; Zhou et al., 1996) decreasing oxidative DNA damage (Boothby and Doering, 2005). The protective effect of Vitamin E ( $\alpha$-tochopherol at the dose of $50 \mathrm{mg} / \mathrm{kg} /$ day for 4 weeks) in the brain (especially hippocampus) was also reported in young hypercholesterolemic rabbits decreasing brain protein carbonylation (Aytan et al., 2008), one of the major risk factors for AD development (Puglielli et al., 2003). All these findings in various animal models indicate that Vitamin E family (tocotrienols and tocopherols) is protective in brain injury and in neurodegeneration with mechanisms involving the inhibition of the lipid peroxidation through the action of various enzymes (pp60 c-Src kinase, ERK1 and ERK2 kinases, Phospholipase A2, 12-Lipoxygenase) and the inhibition of the transcriptional factor NF-кB signaling (Frank et al., 2012). Thus, Vitamin E has a double role acting as antioxidant and anti-inflammatory agent resulting of peculiar importance in aging and neurodegeneration, in which brain oxidative stress and inflammation play a key role in the pathogenesis of dementia, AD and other neurodegenerative diseases. Therefore, a lot of promising and encouraging data against injury brain and dementia obtained in animal models have suggested to perform clinical trials also in humans (Table 6). Despite some papers report that Vitamin E deficiency in the plasma from elderly subjects is associated with cognitive impairment and dementia (Cherubini et al., 2005) and it is a maker to predict the risk of dementia in old people (Di Iorio et al., 2006), there is no strong evidence that Vitamin E supplementation is efficacious in improving outcomes of AD (Morris, 2012). Sano et al. (1997) report that Vitamin E (at the dose of 2000 IU/day for 2 years) has no effect on some endpoints of $A D$, i.e. death, institutionalization, loss of two of three basic activities of daily living, progression of Clinical Dementia Rating (CDR) stage from 2 to 3. More recently, Petersen et al. (2005) and Irizarry et al. (2009) found no difference in cognitive improvement in MILD subjects supplemented with Vitamin E in comparison to placebo group. On the contrary, Lloret et al. (2009) found that a supplementation of Vitamin E (800 IU/day for 6 months) lowers oxidative stress marker (oxidized glutathione GSSG) and maintains cognitive status exclusively in some AD patients. In those subjects where Vitamin E does not prevent oxidative stress, it is detrimental in terms of cognition (Lloret et al., 2009). The same authors concluded that the supplementation of AD patients with Vitamin E cannot be recommended without the previous determination of its antioxidant effect in each patient, as also suggested by Brewer (2010) and Farina et al. (2012). By contrast, it has been reported from the Chicago Health and Aging Project, which monitored the incidence of $\mathrm{AD}$ over 6 years in community residents older than 65 years, that the intake of mixed forms of Vitamin $\mathrm{E}$ ( $\alpha$-tocopherol and $\gamma$-tocopherol) exclusively by food sources was associated with a slower rate of cognitive decline (Morris et al., 2005). These findings were confirmed recently in subjects aged $\geq 80$ years with dementia from the Kungsholmen Project (Mangialasche et al., 2010). After 6 years, subjects with Vitamin E plasma levels in the highest tertile had a reduced risk of $A D$ progression in comparison to persons in the lowest tertile. The neuroprotective effect seems to be related to the combination of different Vitamin $\mathrm{E}$ isoforms, rather than to $\alpha$-tocopherol alone (Mangialasche et al., 2010), whose efficacy in interventions against $\mathrm{AD}$ progression is however currently debated (Usoro and Mousa, 2010), especially in relation to the interaction with concomitant medications (Brigelius-Flohe, 2007). Thus, the exclusive use of the $\alpha$-tocopherol form of Vitamin $\mathrm{E}$ in clinical trials is questioned. Moreover, results from clinical trials of Vitamin E in non-AD neurodegenerative disorders have not been promising. Neither patients with Parkinson's disease (Pham and Plakogiannis, 2005) nor Huntington's disease (Peyser et al., 1995) have shown a significant overall effect for Vitamin E. Without excluding the testing of some oxidative markers as endpoints in order to check the beneficial effect of Vitamin E supplementation (Farina et al., 2012), the Vitamin E-gene interactions may be also crucial in neurodegeneration.

\section{Vitamin E-gene interactions}

As reported in the previous sections, Vitamin E family (tocopherols and tocotrienols) contains various isoforms with potent antioxidant and anti-inflammatory properties. For this reason, a lot of clinical trials in humans have been carried out but, unfortunately, with contradictory and inconsistent results (see previous Section 4). Since Vitamin E interacts with cell receptors (e.g. LDL receptor) and transcription factors (e.g. pregnane $\mathrm{X}$ receptor) thereby driving (redox-regulated) gene expression (e.g. scavenger receptor CD36) and it modulates protein levels (e.g. glutathione) and changes enzyme activity levels (e.g. protein kinase $C$ ), the interaction of Vitamin $\mathrm{E}$ among Vitamin $\mathrm{E}$ and the genes codifying these proteins is crucial for the effects of Vitamin E supplementation. Modulation of enzyme transcription and/or activity by Vitamin $\mathrm{E}$ has been shown in genes involved in oxidative stress, proliferation, inflammation and apoptosis. Such genes include, SOD, NO synthase, cyclooxygenase-2, NAPDH oxidase, NF- $\mathrm{B}$, phospholipase $A 2$, protein phosphatase $2 \mathrm{~A}, 5$-lipooxygenase, activator protein-1, cytochrome P450, BCL2-like 1 and a lot of other genes (Munteanu et al., 2004; Lirangi et al., 2012; Kaga et al., 2013; Zingg et al., 2013). Moreover, $\alpha$-tocopherol transfer protein ( $\alpha$-TTP), $\alpha$-tropomyosin and collagenase are also affected by $\alpha$-tocopherol at the transcriptional level (Azzi et al., 2002). To obtain a comprehensive understanding of the genes affected by Vitamin E, preliminary global gene expression profile experiments using DNA arrays in rat liver and hepatocellular liver carcinoma cells (HepG2) have been conducted in short-term (49 days) and long-term (290 days) of Vitamin E deficiency and then supplemented with Vitamin E (RRR$\alpha$-tocopheryl acetate) (Fischer et al., 2001; Barella et al., 2004; Rimbach et al., 2004). Differential gene expression by DNA arrays comprising up to 7000 genes were measured. Dietary Vitamin E deficiency over a 7-week period did not induce any significant changes in the gene expression profile. By contrast, long term vitamin E deficiency up-regulated coagulation factor IX (FIX), 5$\alpha$-steroid reductase type 1 , and CD36 mRNA levels, while hepatic $\gamma$-glutamyl-cysteinyl synthetase (an index of glutathione synthesis) was down-regulated. Vitamin E supplementation changed coagulation factor IX and CD36 expression in HepG2 cells. These findings suggest that Vitamin $\mathrm{E}$ has more long-term rather than short-term effects especially on liver gene expressions with potential downstream effects on extrahepatic tissues. Of interest is the effect of Vitamin $\mathrm{E}$ on the gene expressions of the various isoforms of cytochrome (CYP) P450 (Mustacich et al., 2006). Such an effect suggests a role of Vitamin $\mathrm{E}$ also in the detoxification 
Table 7

Some target genes regulated at transcriptional level by Vitamin E.

\begin{tabular}{|c|c|c|c|}
\hline Gene class & Gene & Function & Effect of alpha-tocopherol \\
\hline Scavenger receptors & CD36, SR-BI, SR-AI/II & Uptake of oxLDL & Inhibition \\
\hline Extracellular matrix & $\begin{array}{l}\text { E-Selectin, L-Selectin, ICAM-1, Integrins, Mac-1 } \\
\text { Collagen alpha1, glycoprotein IIb, VCAM-1 }\end{array}$ & $\begin{array}{l}\text { Rolling and adhesion of } \\
\text { monocytes/macrophages, platelet adhesion }\end{array}$ & Inhibition \\
\hline Inflammatory cytokines & TGF- $\beta$, IL- 4, IL- $1 \beta$, TNF- $\alpha$ & $\begin{array}{l}\text { Inflammation and chemotaxis of inflammatory } \\
\text { cells }\end{array}$ & Inhibition \\
\hline \multirow[t]{2}{*}{ Cell cycle regulation } & P27 & $\begin{array}{l}\text { Inhibition of smooth muscle cells proliferation } \\
\text { and aortic thickening, }\end{array}$ & Induction \\
\hline & $\begin{array}{l}\text { Cyclin D1, Cyclin E, Cyclin B2, } \\
\text { Cyclin-dependent kinase5, Cdc6-related } \\
\text { protein }\end{array}$ & Induction of proliferation & Inhibition \\
\hline Apoptosis & CD95L (CD95 APO-1/Fas ligand), Bcl2-L1, Birc5 & Induction of apoptosis & Inhibition \\
\hline Regulation of transcription & $\begin{array}{l}\text { NF-кB, AP-1, PKC } \\
\text { Kruppel-like factor3, Ikaros }\end{array}$ & $\begin{array}{l}\text { Induction of inflammatory genes } \\
\text { Induction of immune response }\end{array}$ & $\begin{array}{l}\text { Inhibition } \\
\text { Induction }\end{array}$ \\
\hline Chemotaxis & $\mathrm{Ccl} 2, \mathrm{MCP}-1$ & $\begin{array}{l}\text { Migration and infiltration of } \\
\text { monocytes/macrophages }\end{array}$ & Inhibition \\
\hline Antioxidant defence & Gamma-glutamyl cisteinyl synthetase ( $\gamma$ GCS) & Involved in glutathione biosynthesis pathway & Induction \\
\hline Detoxification & $\begin{array}{l}\text { P450-Cytochromes (Cyp3A, Cyp4F2), Pregnane } \\
\text { X receptor (PXR) }\end{array}$ & $\begin{array}{l}\text { Detoxification of exogenous and endogenous } \\
\text { compounds }\end{array}$ & Induction \\
\hline Cell proliferation & MMP-1, MMP-19 & $\begin{array}{l}\text { Tissue remodeling and inflammatory/immune } \\
\text { response }\end{array}$ & Inhibition \\
\hline Lipid metabolism & ApoE, PPAR- $\gamma$, LDL-R & Lipid uptake, delivery transport & Inhibition \\
\hline \multirow[t]{2}{*}{ Vascular defence } & Haptoglobin (Hp) & $\begin{array}{l}\text { Formation of haptoglobin-hemoglobin } \\
(\mathrm{Hp}-\mathrm{Hb}) \text { complex }\end{array}$ & Induction \\
\hline & PAI-1 & $\begin{array}{l}\text { Inhibition of fibrinolysis and degradation of } \\
\text { blood clots }\end{array}$ & Induction \\
\hline
\end{tabular}

For single references related to the specific gene class see Munteanu et al. (2004), Azzi et al. (2004), Rimbach et al. (2010) and Han et al. (2006).

mechanisms that may result relevant in presence of drugs intake both in aging and age-related diseases. Noteworthy, the more significant results "in vitro" (HepG2 cells) and "in vivo" experimental rats were obtained using natural Vitamin E (RRR- $\alpha$-tocopheryl acetate) rather than synthetic Vitamin E (all-rac-tocopheryl acetate) suggesting that the benefit of Vitamin E-gene interactions comes more from the diet rather than from a supplementation (Rimbach et al., 2010). Such an assumption is supported by the recent discovery in preadipocytes (NIH3T3-L1 cell lines), where $\alpha$-tocopheryl phosphate (but not $\alpha$-tocopherol) activates a set of genes TBR3 (Tribbles Homolog3), Sestrin-2 (SESN2) and insulininduced gene-1 (INSIG-1) preventing fat accumulation in these cells and the consequent lipotoxicity (Lirangi et al., 2012). Subsequently, array technology showed a wide range of genes affected by Vitamin E, including genes related to the inflammation and cell adhesion, cell cycle, extracellular matrix (Rimbach et al., 2010) (see Table 7). Many of these genes play an important role in many inflammatory age-related diseases especially atherosclerosis and CVD, in particular genes related to the cellular adhesion molecules induced by cytokines inside the human vascular endothelia, such as VCAM-1 expressed at the macrophage surfaces (Zapolska-Downar et al., 2000), L-selectin from pulmonary macrophages (Sabat et al., 2001), Mac-1 (CD11/CD18) induced by oxLDL within monocytes (Terasawa et al., 2000). It has been shown that the inhibition of scavenger receptor type SCRA and CD36 expressions at the transcriptional level by $\alpha$-tocopherol in aortic smooth cells (Ricciarelli et al., 2000; Ozer et al., 2006) and monocytes/macrophages (Devaraj et al., 2001) followed by a decreased uptake of oxLDL in these cells, can prevent the formation of the foam cells "in vitro" with a possible inhibition of the atherosclerosis progression (Ozer et al., 2006; Kaga et al., 2013). Such an hypothesis is substained by the fact that $\mathrm{ApoE}^{-1-}$ mice, that are prone to develop atherosclerosis, do not develop atherosclerotic lesion if the CD36 scavenger receptor is absent (Febbraio et al., 2000). The expression of CD36 mRNA is correlated with the lipid peroxide content in peritoneal macrophages during mice aging, and this is accompanied by an age-dependent increase in the cellular uptake of oxLDL (de Winther et al., 2000). Treatment with Vitamin E decreased the amount of cellular lipid peroxides and resulted in the inhibition of macrophage uptake of oxLDL and in cellular CD36 mRNA expression (Fuhrman et al., 2002; Ozer et al., 2006). These findings from "in vitro" experiments and in animals models support the relevance of the Vitamin E-gene interaction in aging and inflammatory age-related diseases. At this regard, a substantial number of papers reports polymorphisms of genes involved in the uptake, distribution, metabolism and secretion of the micronutrient. A number of genetic polymorphisms and epigenetic modifications (that can occur in the homozygote or heterozygote state) may lower the bioavailability and cellular activity of Vitamin E (Rigotti, 2007; Zingg et al., 2008) (Table 8) influencing a differential susceptibility among the people to specific disorders, such as atherosclerosis, diabetes, CVD, cancers, and neurodegenerative diseases, which could be circumvented by Vitamin E supplementation. Despite of these genetic findings, few data exist up to date in Vitamin E supplementation on the basis of specific polymorphisms that can be crucial for the beneficial effect of Vitamin $\mathrm{E}$ (Table 9). In this context, an interesting paper of Testa et al. (2004) shows the relevance of the interaction between Vitamin $\mathrm{E}$ and the gene of plasminogen activator inhibitor type 1 (PAI-1), an independent CVD risk factor, which increases in patients with DM and is closely related to the inflammatory state (De Taeye et al., 2005). The 4G/5G polymorphism of PAI-1 is involved in the incidence of cardiovascular disease by regulation of PAI-1 levels (Grubic et al., 1996). A treatment with Vitamin E (500 IU/die for 10 weeks) in old diabetic patients carrying $4 \mathrm{G}$ allele provoked a delayed decrease in PAI-1 levels with respect to those carrying 5G/5G genotype (Testa et al., 2004). This finding demonstrates that $4 \mathrm{G} / 5 \mathrm{G}$ polymorphism mainly influences the rate of decrease of PAI-1 after supplementation with Vitamin E in diabetes. More recently, Belisle et al. (2009) proposed that single nucleotide polymorphisms may influence individual response to vitamin $\mathrm{E}$ treatment $(182 \mathrm{mg} /$ day for 3 years) in terms of proinflammatory cytokine production (TNF- $\alpha$ ). Old subjects with the A/A and A/G genotypes at TNF- $\alpha-308 \mathrm{G}>\mathrm{A}$ treated with Vitamin $\mathrm{E}$ had lower TNF- $\alpha$ production than those with the A allele treated 
Table 8

Some relevant genes possibly affecting Vitamin E bioactivity in relation to their polymorphisms.

\begin{tabular}{|c|c|c|c|}
\hline Candidate genes & Function in relation to Vit. E & $\begin{array}{l}\text { Effects on Vit.E bioactivity by } \\
\text { polymorphisms }\end{array}$ & Reference \\
\hline Haptoglobin (Hp) & Increased free radicals in Vit.E deficiency & Increased free radicals in $\mathrm{Hp}-2-2$ genotype & Milman et al. (2008) \\
\hline Apolipoprotein E (ApoE) & $\begin{array}{l}\text { Increased free radicals in Vit.E deficiency; } \\
\text { plasma lipoprotein on Vit.E turnover }\end{array}$ & $\begin{array}{l}\text { ApoE4 genotype is associated with } \\
\text { increased levels of Vit.E }\end{array}$ & Borel et al. (2007) \\
\hline SR-BI scavenger receptor & Vit.E uptake and transport & Influence of Vit.E levels in cell and tissue & Borel et al. (2007) \\
\hline CD36 scavenger receptor & $\begin{array}{l}\text { Reduced gene expression of CD } 36 \text { by Vit.E } \\
\text { with no formation of foam cells }\end{array}$ & Influence on the responsiveness to Vit.E & Zingg et al. (2002) \\
\hline LDL-receptor & Removal of LDL from plasma & Influence on plasma lipid profile & Döring et al. (2004) \\
\hline$\alpha$-Tocopherol transfer protein ( $\alpha$-TTP) & Vit.E retention in plasma & Influence of plasma and tissue level of Vit. E & Döring et al. (2004) \\
\hline Pregnane $\mathrm{X}$ receptor $(\mathrm{PXR})$ & Vit.E-mediated gene expression & $\begin{array}{l}\text { Influence on PXR target genes for } \\
\text { detoxification }\end{array}$ & Döring et al. (2004) \\
\hline P450-cytochromes (Сyp3A, Cyp4F2) & Vit.E metabolism & $\begin{array}{l}\text { Influence on metabolites deriving from } \\
\text { detoxification }\end{array}$ & Döring et al. (2004) \\
\hline TNF-alpha & Decreased inflammation & $\begin{array}{l}\text { Influence on better inflammatory/immune } \\
\text { response by Vit.E }\end{array}$ & Belisle et al. (2009) \\
\hline $\begin{array}{l}\text { Plasminogen activator inhibitor type } 1 \\
\text { (PAI-1) }\end{array}$ & Control of fibrinolysis by Vit.E & Delayed and low production of PAI-1 & Testa et al. (2004) \\
\hline $\begin{array}{l}\text { Tocopherol associated protein (TAP1, } \\
\text { TAP2, TAP 3) }\end{array}$ & $\begin{array}{l}\text { Vit.E binding, uptake, signal transduction, } \\
\text { gene expression }\end{array}$ & Influence on Vit.E on cellular activity & Döring et al. (2004) \\
\hline Afamin & Vit.E transport into the brain & Influence of Vit.E in the nervous system & Voegele et al. (2002) \\
\hline Lipoprotein lipase (LPL) & $\begin{array}{l}\text { Transfer of Vit.E from lipoprotein into } \\
\text { peripheral tissues }\end{array}$ & $\begin{array}{l}\text { Influence on Vit.E content in plasma, } \\
\text { tissues and cells }\end{array}$ & Borel et al. (2007) \\
\hline
\end{tabular}

with placebo. Since the A allele at TNF- $\alpha-308 \mathrm{G}>\mathrm{A}$ is associated with higher TNF- $\alpha$ levels (Cipriano et al., 2005), these results suggest that the anti-inflammatory effect of Vitamin E may be specific to subjects genetically predisposed to higher inflammation. Moreover, the interactions between Vitamin $\mathrm{E}$ and $\mathrm{Hp}$ gene or ApoE gene are intriguing. As reported above, the Hp gene, the hapoglobin production and the Hp-Hb complex formation via CD163 receptor activation on macrophages, are involved in diabetes with CVD complications. In humans, the Hp gene exists mainly as two alleles $\mathrm{Hp} 1$ and $\mathrm{Hp} 2$, leading to haptoglobin 1-1, 1-2, and 2-2 genotypes. The Hp-1-1 genotype is associated with resistance to the development of diabetic retinopathy, diabetic nephropathy and CVD because the Hb-Hp 1-1 complex is readily recognized by CD163 and more rapidly cleared with subsequent low oxidative damage caused by hemoglobin (Tseng et al., 2004). In contrast, the Hp 2-2 protein binds with more affinity to hemoglobin, but this complex is less efficiently cleared leading to oxidative damage to the vascular wall (Blum et al., 2007). In this situation, supplementation with Vitamin E in Hp-2-2 genotype shows potent preventive effects (Milman et al., 2008; Vardi et al., 2012). With regard to ApoE, ApoE4 genotype is associated with increased morbidity and mortality, and represents a significant risk factor for CVD cardiovascular disease and late-onset AD (Liu et al., 2013). ApoE is an important modulator of many stages of the lipoprotein metabolism as well as possesses immunomodulatory/anti-inflammatory properties. An increasing number of studies in cell lines (Huebbe et al., 2007), transgenic rodents (Jofre-Monseny et al., 2007) and AD (Jofre-Monseny et al., 2008 ) indicate higher oxidative stress and pro-inflammatory state associated with the $\varepsilon 4$ allele (Jofre-Monseny et al., 2008). AD carrying E4 allele better counteract to the adverse effect of oxidative stress and chronic inflammation than do non-E4 carriers (Tanzi and Bertram, 2001). Therefore, the polymorphisms of Hp and ApoE may be crucial points for the benefit of Vitamin E supplementation in diabetes, $A D$, in inflammation and neurodegeneration. In addition, a significant number of genes was found to be regulated by Vitamin $\mathrm{E}$, such as nerve growth factor, dopaminerigic neurotrasmitters, and clearance of amyloid- $\beta$ in the rat brain (Rota et al., 2005). Old smokers carrying specific alleles for ApoE polymorphism, SR-BI scavenger receptor, lipoprotein lipase (LPL) have high levels of Vitamin E coupled with low levels of cholesterol and triglycerides (Borel et al., 2007), suggesting the presence of a protective state by these polymorphisms in old smokers carrying specific alleles. Therefore, the individual genetic background is pivotal for the success of a personalized Vitamin E supplementation in condition of severe oxidative stress and inflammation. Finally, an aspect that deserves a great attention is the influence of Vitamin E on miRNA (Rimbach et al., 2010), taking into account that mature miRNA affects posttranscriptional gene expression by binding at the $3^{\prime}$ untranslated region of mRNA and inhibiting their translation into proteins (Boyd, 2008). At the same time, miRNA are encoded in the genome and are liable to regulation. Rats with diets deficient or sufficient in Vitamin E (RRR- $\alpha$-tocopherol) were used and analyzed for miRNA concentrations in the liver. Two miRNA previously involved in the process associated to Vitamin E, namely miRNA-122a involved in lipid metabolism (Esau et al., 2006) and miRNA-125b implicated in cancer progression and inflammation (Ozen et al., 2008) were selected. Vitamin E deficiency resulted in decreased levels of both miRNA-122a and miRNA-125b (Gaedicke et al., 2008; Rimbach et al., 2010) with no effect on DNA metylation (Fischer et al., 2010). A decrease of miRNA-125b resulted in increased TNF- $\alpha$

Table 9

Vitamin E supplementation on the basis of some polymorphisms affecting Vitamin E bioactivity.

\begin{tabular}{|c|c|c|c|c|c|}
\hline Dose of Vitamin E & Condition & Gene target & Genotype & Effect & References \\
\hline $500 \mathrm{IU} /$ day for 10 weeks & $\begin{array}{l}\text { Type } 2 \text { diabetes } \\
\text { n.93 } \geq 60 \text { years }\end{array}$ & $\begin{array}{l}\text { 4G/5G } \\
\text { Polymorphism of PAI-1 }\end{array}$ & $\begin{array}{l}4 G / 4 G 4 G / 5 G \\
5 G / 5 G\end{array}$ & $\begin{array}{l}\text { Faster decrement in PAI-1 } \\
\text { Low decrement in PAI-1 }\end{array}$ & Testa et al. (2004) \\
\hline $182 \mathrm{mg} /$ day for 3 years & $\begin{array}{l}\text { Healthy aging } \\
\text { n. } 617 \geq 65 \text { years }\end{array}$ & TNF- $\alpha-308$ G/A & $\begin{array}{ll}A / A & A / G \\
G / G\end{array}$ & $\begin{array}{l}\text { Low TNF-production } \\
\text { No effect }\end{array}$ & Belisle et al. (2009) \\
\hline $400 \mathrm{IU} /$ day for 18 months & $\begin{array}{l}\text { Type } 2 \text { diabetes } \\
\text { n.726 } \geq 65 \text { years }\end{array}$ & Haptoglobin (Hp) & $\begin{array}{l}\text { Hp 1-1Hp 2-1 } \\
\text { Hp 2-2 }\end{array}$ & $\begin{array}{l}\text { No effect on cardiovascular events } \\
\text { (MI, stroke, mortality) } \\
\text { Reduction of cardiovascular events } \\
\text { (MI, stroke, mortality) }\end{array}$ & Milman et al. (2008) \\
\hline
\end{tabular}


1251 production and inflammation in LPS stimulated macrophages (Tili 1252 et al., 2007). Thus, the reduced miRNA-125b levels observed in 1253 Vitamin E-deficient rats may be associated with an enhanced 1254 inflammatory response, as previously described (Yamaoka et al., 1255 2008). These findings indicate that Vitamin E regulates cell 1256 signaling not only at mRNA level but also at miRNA level. From 1257 all the data regarding to Vitamin E-gene interactions emerges the 1258 pivotal role played by the specific genetic background for a posi1259 tive effect of Vitamin $\mathrm{E}$ as antioxidant and anti-inflammatory agent. 1260 However, the study in this field of miRNA is still in infancy and 1261 future research is required for definitive guidelines addressed to 1262 a more correct and personalized Vitamin E supplementation in 1263 relation to miRNA.

\section{6. Conclusions and future perspectives}

While is out of doubt the relevance of Vitamin E as antioxidant and anti-inflammatory compound for the whole life of an organism with a special emphasis in aging and in some inflammatory age related diseases, a critical point is the translation of the benefit of Vitamin $\mathrm{E}$ in human clinical trials. Experiments in various cell cultures and in different animal models have clearly shown that Vitamin $\mathrm{E}$ is an essential dietary compound for the efficiency of many body homeostatic mechanisms with a particular focus on the immune system. In particular, the cell-mediated immunity and the inflammatory/immune response are preserved by the lipid peroxide formation on $\mathrm{CD}^{+}$cells both in aging and inflammatory age-related diseases. As a consequence, the production of IL-2 is satisfactory with a good immune response to external noxae. On the other hand, the presence of good circulating levels in centenarians of Vitamin E coupled with satisfactory antioxidant activity and immune response (Mecocci et al., 2000), clearly testify the relevance of Vitamin $\mathrm{E}$ in the economy of the immune and antioxidant performances required to achieve healthy aging and longevity. However, the various isoforms of the Vitamin E family do not have similar beneficial effects. The more known isoform of Vitamin E ( $\alpha$-tocopherol) seems to have the major properties either as antioxidant or anti-inflammatory agent in various experimental conditions. However recently, another isoform of Vitamin $\mathrm{E}$ ( $\boldsymbol{\gamma}$-tocopherol) and tocotrienols ( $\delta$-tocotrienol) seem to have more precise antioxidant properties in affecting the inflammatory/immune response in aging and in age-related diseases, such as cancer and neurodegeneration. Such a more potent effect of $\gamma$-tocopherol and $\delta$-tocotrienol mainly occur in "in vitro" models using specific cancer cell lines. When transferred in animal models, for example in cancer models of mice, the supplementation with the various isoforms of tocopherols and tocotrienols, gives often inconsistent and contradictory results especially in the rate of the survival. On the contrary, a mixture of the various isoforms of Vitamin E and tocotrienols (named TRF and $\gamma$-TmT) has more efficacy in reducing DNA damage, restoring the inflammatory/immune response and protecting the immune cells by ROS with direct mechanisms involving CD3/TCR complex and lipid rafts on cell membrane. These encouraging results in experimental conditions have suggested to perform a lot of clinical trials in humans, both in elderly and in the more common inflammatory age-related diseases, in which both the oxidative stress and the chronic inflammation are the main cause of their onset and progression. However, the results of clinical trials are contradictory. It is possible that inadequate subject selection (by sex, Vitamin E status, genetic polymorphisms), the presence of advanced lesions, and the dosage and chemical form of Vitamin E administered may partly explain the incongruence between the reporting data. In this context, it is also relevant to note that the effect of Vitamin $\mathrm{E}$ is more at long-term than short-term and the dosage of Vitamin E should not exceed $400 \mathrm{IU} /$ day. Moreover, the best results can be obtained using a mixture of the various isoforms of Vitamin $\mathrm{E}$ family including tocotrienols. The use of a single isoform of Vitamin $\mathrm{E}$ ( $\alpha$-tocopherol) at high doses can lead to unexpected results, especially in atherosclerosis, with the rupture of the atherosclerotic plaque and risk of thrombosis and mortality (Miller et al., 2005a; Saremi and Arora, 2010). Risk of mortality can also occur in adult smokers against pulmonary infection progression (ATBC study) (Hemila and Kaprio, 2009) as well as in old frail people (Bjelakovic et al., 2012; Thomas et al., 2006) with still undefined and unclear mechanisms explaining the mortality by high dose of Vitamin E. However, the major incongruence in human clinical trials may be related to the specific genetic background from each individual. Such an assumption is supported by two different approaches with Vitamin E supplementation in restoring the inflammatory/immune response in aging (Belisle et al., 2009) and in reducing the insulin resistance in DM (Testa et al., 2004) on the basis of TNF- $\alpha$ and PAI-1 polymorphisms, respectively. Moreover, polymorphisms of ApoE may be useful for Vitamin E supplementation against oxidative stress and inflammation in late Alzheimer's disease (Tanzi and Bertram, 2001) and in old smokers (Borel et al., 2007). An intriguing point is that Vitamin E supplementation in diabetic patients carrying Hp 2-2 genotype leads to a low risk to develop CVD risk (Milman et al., 2012). Therefore, the interaction of Vitamin E with genes related to its bioactivity is fundamental for the success of the clinical trials with Vitamin E supplementation in aging and in inflammatory age-related diseases. This interaction should be evaluated also at post-translational level taking into account that Vitamin E affects miRNA. Since miRNA play a pivotal role in cancer and CVD (Dimmeler and Nicotera, 2013), future research addressing both in nutrigenomic and nutrigenetic approaches as well as in miRNA for Vitamin E supplementation is strongly recommended in order to give precise and personalized guidelines for Vitamin E supplementation in clinical practice. More clinical trials need to be carried out considering this peculiar aspect of the Vitamin E-gene interactions. As such, the essential micronutrient Vitamin E can be correctly used in a personalized way either for the outcome from the pathology or to achieve healthy aging and longevity without any adverse effects.

\section{Conflicts of interest}

No authors have conflicts of interest.

\section{Uncited references}

Cook et al. (2007) and O’Donnell and Lynch (1998).

\section{Acknowledgements}

Supported by INRCA, European Markage Project (FP7, HEALTHF4-2008 no. 200880); European NuAge Project (FP7 KBBE-2010-4 no. 266486), Italian Health Ministry (R.F. 154/GR no. 2009-1584108 "My Mind").

\section{References}

Abdala-Valencia, H., Berdnikovs, S., Cook-Mills, J.M., 2012. Vitamin E isoforms differentially regulate intercellular adhesion molecule- 1 activation of $\mathrm{PKC} \alpha$ in human

Abner, E.L., Schmitt, F.A., Mendiondo, M.S., Marcum, J.L., Kryscio, R.J., 2011. Vitamin E and all-cause mortality: a meta-analysis. Curr. Aging Sci. 4, 158-170.

ACCORD STUDY. Action to Control Cardiovascular Risk in Diabetes Study GroupGerstein, H.C., Miller, M.E., Byington, R.P., Goff Jr., D.C., Bigger, J.T., Buse, J.B., Cushman, W.C., Genuth, S., Ismail-Beigi, F., Grimm Jr., R.H., Probstfield, J.L., Simons-Morton, D.G., Friedewald, W.T., 2008. Effects of intensive glucose lowering in type 2 diabetes. N. Engl. J. Med. 358, 2545-2559.

ACCORD STUDYCushman, W.C., Evans, G.W., Byington, R.P., Goff Jr., D.C., Grimm Jr., R.H., Cutler, J.A., Simons-Morton, D.G., Basile, J.N., Corson, M.A., Probstfield, microvascular endothelial cells. PLoS ONE 7, e41054-e41058. 
J.L., Katz, L., Peterson, K.A., Friedewald, W.T., Buse, J.B., Bigger, J.T., Gerstein, H.C., Ismail-Beigi, F., 2010a. Effects of intensive blood-pressure control in type 2 diabetes mellitus. N. Engl. J. Med. 362, 1575-1585.

ACCORD STUDYGinsberg, H.N., Elam, M.B., Lovato, L.C., Crouse 3rd., J.R., Leiter, L.A Linz, P., Friedewald, W.T., Buse, J.B., Gerstein, H.C., Probstfield, J., Grimm, R.H., Ismail-Beigi, F., Bigger, J.T., Goff Jr., D.C., Cushman, W.C., Simons-Morton, D.G., Byington, R.P., 2010b. Effects of combination lipid therapy in type 2 diabetes mellitus. N. Engl. J. Med. 362, 1563-1574.

Adolfsson, O., Huber, B.T., Meydani, S.N., 2001. Vitamin E-enhanced IL-2 production in old mice: naive but not memory T cells show increased cell division cycling and IL-2-producing capacity. J. Immunol. 167, 3809-3817.

Aggarwal, B.B., Sundaram, C., Prasad, S., Kannappan, R., 2010. Tocotrienols, the Vitamin $E$ of the 21 st century: its potential against cancer and other chronic diseases. Biochem. Pharmacol. 80, 1613-1631.

Ames, B.N., 2006. Low micronutrient intake may accelerate the degenerative diseases of aging through allocation of scarce micronutrients by triage. Proc. Natl. Acad. Sci. U.S.A. 103, 17589-17594.

Arad, Y., Goodman, K.J., Roth, M., Newstein, D., Guerci, A.D., 2005. Coronary calcification, coronary disease risk factors, C-reactive protein, and atherosclerotic cardiovascular disease events: the St. Francis Heart Study. J. Am. Coll. Cardiol. $46,158-165$.

Asleh, R., Marsh, S., Shilkrut, M., Binah, O., Guetta, J., Lejbkowicz, F., Enav, B., Shehadeh, N., Kanter, Y., Lache, O., Cohen, O., Levy, N.S., Levy, A.P., 2003. Genetically determined heterogeneity in hemoglobin scavenging and susceptibility to diabetic cardiovascular disease. Circ. Res. 92, 1193-1200.

ATBC Study. Alpha-Tocopherol, Beta Carotene Cancer Prevention Study Group, 1994 The effect of vitamin $\mathrm{E}$ and beta carotene on the incidence of lung cancer and other cancers in male smokers. N. Engl. J. Med. 330, 1029-1035.

Aytan, N., Jung, T., Tamtürk, F., Grune, T., Kartal-Ozer, N., 2008. Oxidative stress related changes in the brain of hypercholesterolemic rabbits. Biofactors 33 225-236.

Azzi, A., 2007. Molecular mechanism of alpha-tocopherol action. Free Radic. Biol. Med. 43, 16-21.

Azzi, A., Stocker, A., 2000. Vitamin E: non-antioxidant roles. Prog. Lipid Res. 39, 231-255.

Azzi, A., Gysin, R., Kempna, P., Munteanu, A., Negis, Y., Villacorta, L., Visarius, T., Zingg, J.M., 2004. Vitamin E mediates cell signaling and regulation of gene expression. Ann. N. Y. Acad. Sci. 1031, 86-95.

Azzi, A., Ricciarelli, R., Zingg, J.M., 2002. Non-antioxidant molecular functions of alpha-tocopherol (vitamin E). FEBS Lett. 519, 8-10.

Bahadorani, S., Bahadorani, P., Phillips, J.P., Hilliker, A.J., 2008. The effects of vitamin supplementation on Drosophila life span under normoxia and under oxidative stress. J. Gerontol. A, Biol. Sci. Med. Sci. 63, 35-42.

Baier, G., 2003. The PKC gene module: molecular biosystematics to resolve its T cell functions. Immunol. Rev. 192, 64-79.

Bakris, G.L., 2011. Recognition, pathogenesis, and treatment of different stages of nephropathy in patients with type 2 diabetes mellitus. Mayo Clin. Proc. 86 444-456.

Barella, L., Muller, P.Y., Schlachter, M., Hunziker, W., Stocklin, E., Spitzer, V., Meier, N., de Pascual-Teresa, S., Minihane, A.M., Rimbach, G., 2004. Identification of hepatic molecular mechanisms of action of alpha-tocopherol using global gene expression profile analysis in rats. Biochem. Biophys. Acta 1689, 66-74.

Bartłomiej, S., Justyna, R.K., Ewa, N., 2012. Bioactive compounds in cereal grains - occurrence, structure, technological significance and nutritional benefits - a review. Food Sci. Technol. Int. 18, 559-568.

Barve, A., Khor, T.O., Nair, S., Reuhl, K., Suh, N., Reddy, B., Newmark, H., Kong, A.N. 2009. Gamma-tocopherol-enriched mixed tocopherol diet inhibits prostate carcinogenesis in TRAMP mice. Int. J. Cancer 124, 1693-1699.

Battaini, F., Pascale, A., 2005. Protein kinase C signal transduction regulation in physiological and pathological aging. Ann. N. Y. Acad. Sci. 1057, 177-192.

Beharka, A.A., Wu, D., Serafini, M., Meydani, S.N., 2002. Mechanism of vitamin E inhibition of cyclooxygenase activity in macrophages from old mice: role of peroxynitrite. Free Radic. Biol. Med. 32, 503-511.

Behl, C., Davis, J., Cole, G.M., Schubert, D., 1992. Vitamin E protects nerve cells from amyloid beta protein toxicity. Biochem. Biophys. Res. Commun. 186, 944-950.

Belisle, S.E., Leka, L.S., Delgado-Lista, J., Jacques, P.F., Ordovas, J.M., Meydani, S.N., 2009. Polymorphisms at cytokine genes may determine the effect of vitamin on cytokine production in the elderly. J. Nutr. 139, 1855-1860.

Biesalski, H.K., Grune, T., Tinz, J., Zollner, I., Blumberg, J.B., 2010. Reexamination of a meta-analysis of the effect of antioxidant supplementation on mortality and health in randomized trials. Nutrients 2, 929-949.

Bjelakovic, G., Nikolova, D., Gluud, L.L., Simonetti, R.G., Gluud, C., 2012. Antioxidant supplements for prevention of mortality in healthy participants and patients with various diseases. Cochrane Database Syst. Rev. 3, Art. No: CD007176.

Blum, S., Asaf, R., Guetta, J., Miller-Lotan, R., Asleh, R., Kremer, R., Levy, N.S., Berger, F.G., Aronson, D., Fu, X., Zhang, R., Hazen, S.L., Levy, A.P., 2007. Haptoglobin genotype determines myocardial infarct size in diabetic mice. J. Am. Coll. Cardiol. 49 $82-87$

Boaz, M., Smetana, S., Weinstein, T., Matas, Z., Gafter, U., Iaina, A., Knecht, A., Weissgarten, Y., Brunner, D., Fainaru, M., Green, M.S., 2000. Secondary prevention with antioxidants of cardiovascular disease in endstage renal disease (SPACE) randomised placebo-controlled trial. Lancet 356, 1213-1218.

Boothby, L.A., Doering, P.L., 2005. Vitamin C and vitamin E for Alzheimer's disease. Ann. Pharmacother. 39, 2073-2080.

Borel, P., Moussa, M., Reboul, E., Lyan, B., Defoort, C., Vincent-Baudry, S., Maillot M., Gastaldi, M., Darmon, M., Portugal, H., Planells, R., Lairon, D., 2007. Human plasma levels of vitamin $\mathrm{E}$ and carotenoids are associated with genetic polymorphisms in genes involved in lipid metabolism. J. Nutr. 137, 2653-2659.

Boscoboinik, D., Szewczyk, A., Hensey, C., Azzi, A., 1991. Inhibition of cell proliferation by alpha-tocopherol. Role of protein kinase C. J. Biol. Chem. 266, 6188-6194.

Boyd, S.D., 2008. Everything you wanted to know about small RNA but were afraid to ask. Lab. Invest. $88,569-578$.

Brewer, G.J., 2010. Why vitamin E therapy fails for treatment of Alzheimer's disease. J. Alzheimers Dis. 19, 27-30.

Brigelius-Flohe, R., 2003. Vitamin E and drug metabolism. Biochem. Biophys. Res. Commun. 305, 737-740.

Brigelius-Flohe, R., 2007. Adverse effects of vitamin E by induction of drug metabolism. Genes Nutr. 2, 249-256.

Brigelius-Flohe, R., Traber, M.G., 1999. Vitamin E: function and metabolism. FASEB J. 13, 1145-1155.

Brigelius-Flohe, R., Kelly, F.J., Salonen, J.T., Neuzil, J., Zingg, J.M., Azzi, A., 2002. The European perspective on vitamin E: current knowledge and future research. Am. J. Clin. Nutr. 76, 703-716.

Bromley, D., Anderson, P.C., Daggett, V., 2013. Structural consequences of mutations to the alpha-tocopherol transfer protein associated with the neurodegenerative disease ataxia with vitamin E deficiency. Biochemistry 52, 4264-4273.

Burton, G.W., Cheeseman, K.H., Doba, T., Ingold, K.U., Slater, T.F., 1983. Vitamin E as an antioxidant in vitro and in vivo. Ciba Found. Symp. 101, 4-18.

Burton, G.W., Cheng, S.C., Webb, A., Ingold, K.U., 1986. Vitamin E in young and old human red blood cells. Biochem. Biophys. Acta 860, 84-90.

Campisi, J., 2000. Cancer, aging and cellular senescence. In Vivo 14, 183-188.

Cao, G., Booth, S.L., Sadowski, J.A., Prior, R.L., 1998. Increases in human plasma antioxidant capacity after consumption of controlled diets high in fruit and vegetables. Am. J. Clin. Nutr. 68, 1081-1087.

Carr, A.C., Zhu, B.Z., Frei, B., 2000. Potential antiatherogenic mechanisms of ascorbate (vitamin C) and alpha-tocopherol (vitamin E). Circ. Res. 87, 349-354.

Casoli, T., Di Stefano, G., Delfino, A., Fattoretti, P., Bertoni-Freddari, C., 2004 Vitamin E deficiency and aging effect on expression levels of GAP-43 and MAP-2 in selected areas of the brain. Ann. N. Y. Acad. Sci. 1019, 37-40.

Catalgol, B., Batirel, S., Ozer, N.K., 2011. Cellular protection and therapeutic potential of tocotrienols. Curr. Pharm. Des. 17, 2215-2220.

Catalgol, B., Kartal-Ozer, N., 2010. Lipid rafts and redox regulation of cellular signaling in cholesterol induced atherosclerosis. Curr. Cardiol. Rev. 6, 309-324

Chan, A.C. 1993. Partners in defense, vitamin E and vitamin C. Can. J. Physiol. Pharmacol. 71, 725-731.

Chen, M.F., Hsu, H.C., Liau, C.S., Lee, Y.T., 1998. Vitamin E supplementation attenuates myointimal proliferation of the abdominal aorta after balloon injury in dietinduced hypercholesterolemic rabbits. Prostaglandins Other Lipid Mediat. 56 219-238.

Cherubini, A., Martin, A., Andres-Lacueva, C., Di Iorio, A., Lamponi, M., Mecocci, P. Bartali, B., Corsi, A Senin, U, Ferrucci, L, 2005. Vitamin E levels, cognitive impairment and dementia in older persons: the InCHIANTI study. Neurobiol. Aging 26, 987-994.

Cherubini, A., Zuliani, G., Costantini, F., Pierdomenico, S.D., Volpato, S., Mezzetti, A. Mecocci, P., Pezzuto, S., Bregnocchi, M., Fellin, R., Senin, U., VASA Study Group, 2001. High vitamin E plasma levels and low low-density lipoprotein oxidation are associated with the absence of atherosclerosis in octogenarians. J. Am. Geriatr. Soc. 49, 651-654.

Chin, S.F., Hamid, N.A., Latiff, A.A., Zakaria, Z., Mazlan, M., Yusof, Y.A., Karim, A.A. Ibahim, J., Hamid, Z., Ngah, W.Z., 2008. Reduction of DNA damage in older healthy adults by Tri E Tocotrienol supplementation. Nutrition 24, 1-10.

Chin, S.F., Ibahim, J., Makpol, S., Abdul Hamid, N.A., Abdul Latiff, A.,Zakaria, Z., Mazlan, M., Mohd Yusof, Y.A., Abdul Karim, A., Wan Ngah, W.Z., 2011. Tocotrienol rich fraction supplementation improved lipid profile and oxidative status in healthy older adults: a randomized controlled study. Nutr. Metab. 8, 42-50.

Cipriano, C., Caruso, C., Lio, D., Giacconi, R., Malavolta, M., Muti, E., Gasparini, N. Franceschi, C., Mocchegiani, E., 2005. The -308G/A polymorphism of TNF-alpha influences immunological parameters in old subjects affected by infectious diseases. Int. J. Immunogenet. 32, 13-18.

Clarke, M.W., Burnett, J.R., Croft, K.D., 2008. Vitamin E in human health and disease. Crit. Rev. Clin. Lab. Sci. 45, 417-450.

Claycombe, KJ., Meydani, S.N., 2001. Vitamin E and genome stability. Mutat. Res. 475, 37-44.

Cook, N.R., Albert, C.M., Gaziano, J.M., Zaharris, E., MacFadyen, J., Danielson, E., Buring, J.E., Manson, J.E., 2007. A randomized factorial trial of vitamins $\mathrm{C}$ and $\mathrm{E}$ and beta carotene in the secondary prevention of cardiovascular events in women: results from the Women's Antioxidant Cardiovascular Study. Arch. Intern. Med. $167,1610-1618$

Coquette, A., Vray, B. Vanderpas, J., 1986. Role of vitamin E in the protection of the resident macrophage membrane against oxidative damage. Arch. Int. Physiol. Biochim. 94, S29-S34.

Cyrus, T., Yao, Y., Rokach, J., Tang, L.X., Praticò, D., 2003. Vitamin E reduces progres sion of atherosclerosis in low-density lipoprotein receptor-deficient mice with established vascular lesions. Circulation 107, 521-523.

Daynes, R.A., Enioutina, E.Y., Jones, D.C., 2003. Role of redox imbalance in the molecular mechanisms responsible for immunosenescence. Antioxid. Redox Signal. 5 , 537-548.

de Gaetano, G., Collaborative Group of the Primary Prevention Project, 2001. Lowdose aspirin and vitamin $\mathrm{E}$ in people at cardiovascular risk: a randomised trial in general practice. Collaborative Group of the Primary Prevention Project. Lancet 357, 89-95. 
De la Fuente, M., Hernanz, A., Guayerbas, N., Victor, V.M., Arnalich, F., 2008. Vitamin E ingestion improves several immune functions in elderly men and women. Free Radic. Res. 42, 272-280.

De Taeye, B., Smith, L.H., Vaughan, D.E., 2005. Plasminogen activator inhibitor-1: a common denominator in obesity, diabetes and cardiovascular disease. Curr. Opin. Pharmacol. 5, 149-154.

de Winther, M.P., van Dijk, K.W., Havekes, L.M., Hofker, M.H., 2000. Macrophage scavenger receptor class A: a multifunctional receptor in atherosclerosis. Arterioscler. Thromb. Vasc. Biol. 20, 290-297.

Devaraj, S., Jialal, I., 1999. Alpha-tocopherol decreases interleukin-1 beta release from activated human monocytes by inhibition of 5-lipoxygenase. Arterioscler. Thromb. Vasc. Biol. 19, 1125-1133.

Devaraj, S., Hugou, I., Jialal, I., 2001. Alpha-tocopherol decreases CD36 expression in human monocyte-derived macrophages. J. Lipid Res. 42, 521-527.

Di Donato, I., Bianchi, S., Federico, A., 2010. Ataxia with vitamin E deficiency: update of molecular diagnosis. Neurol. Sci. 31, 511-515.

Di Iorio, A., Cherubini, A., Volpato, S., Sparvieri, E., Lauretani, F., Franceschi, C., Senin, U., Abate, G., Paganelli, R., Martin, A., Andres-Lacueva, C., Ferrucci, L., 2006. Markers of inflammation, vitamin $\mathrm{E}$ and peripheral nervous system function: the InCHIANTI study. Neurobiol. Aging 27, 1280-1288.

Dimmeler, S., Nicotera, P., 2013. MicroRNAs in age-related diseases. EMBO Mol. Med. $5,180-190$.

Döring, F., Rimbach, G., Lodge, J.K., 2004. In silico search for single nucleotide polymorphisms in genes important in vitamin E homeostasis. IUBMB Life 56, 615-620.

Ekstrand-Hammarstrom, B., Osterlund, C., Lilliehook, B., Bucht, A., 2007. Vitamin E down-modulates mitogen-activated protein kinases, nuclear factor-kappaB and inflammatory responses in lung epithelial cells. Clin. Exp. Immunol. 147, 359-369.

Engelhart, M.J., Geerlings, M.I., Ruitenberg, A., van Swieten, J.C., Hofman, A., Witteman, J.C., Breteler, M.M., 2002. Dietary intake of antioxidants and risk of Alzheimer disease. JAMA 287, 3223-3229.

Ernst, I.M., Pallauf, K., Bendall, J.K., Paulsen, L., Nikolai, S., Huebbe, P., Roeder, T., Rimbach, G., 2013. Vitamin E supplementation and lifespan in model organisms. Ageing Res. Rev. 12, 365-375.

Esau, C., Davis, S., Murray, S.F., Yu, X.X., Pandey, S.K., Pear, M., Watts, L., Booten, S.L., Graham, M., McKay, R., Subramaniam, A., Propp, S., Lollo, B.A., Freier, S., Bennett, C.F., Bhanot, S., Monia, B.P., 2006. miR-122 regulation of lipid metabolism revealed by in vivo antisense targeting. Cell Metab. 3, 87-98.

Farina, N., Isaac, M.G., Clark, A.R., Rusted, J., Tabet, N., 2012. Vitamin E for Alzheimer's dementia and mild cognitive impairment. Cochrane Database Syst. Rev. 11, 1-31, Art. No: CD002854.

Febbraio, M., Podrez, E.A., Smith, J.D., Hajjar, D.P., Hazen, S.L., Hoff, H.F., Sharma, K., Silverstein, R.L., 2000. Targeted disruption of the class B scavenger receptor CD36 protects against atherosclerotic lesion development in mice. J. Clin. Invest. $105,1049-1056$.

Fischer, A., Gaedicke, S., Frank, J., Doring, F., Rimbach, G., 2010. Dietary vitamin E deficiency does not affect global and specific DNA methylation patterns in rat liver. Br. J. Nutr. 104, 935-940.

Fischer, A., Pallauf, J., Gohil, K., Weber, S.U., Packer, L., Rimbach, G., 2001. Effect of selenium and vitamin E deficiency on differential gene expression in rat liver. Biochem. Biophys. Res. Commun. 285, 470-475.

Forbes, J.M., Cooper, M.E., 2013. Mechanisms of diabetic complications. Physiol. Rev. 93, 137-188.

Fortin, C.F., Larbi, A., Lesur, O., Douziech, N., Fulop Jr., T., 2006. Impairment of SHP-1 down-regulation in the lipid rafts of human neutrophils under GM-CSF stimulation contributes to their age-related, altered functions. J. Leukoc. Biol. 79 1061-1072.

Franceschi, C., Bonafe, M., Valensin, S., Olivieri, F., De Luca, M., Ottaviani, E., De Benedictis, G., 2000. Inflammaging. An evolutionary perspective on immunosenescence. Ann. N. Y. Acad. Sci. 908, 244-254.

Franceschi, C., Capri, M., Monti, D., Giunta, S., Olivieri, F., Sevini, F., Panourgia, M.P., Invidia, L., Celani, L., Scurti, M., Cevenini, E., Castellani, G.C., Salvioli, S., 2007. Inflammaging and anti-inflammaging: a systemic perspective on aging and longevity emerged from studies in humans. Mech. Ageing Dev. 128, 92-105

Frank, J., Chin, X.W., Schrader, C., Eckert, G.P., Rimbach, G., 2012. Do tocotrienols have potential as neuroprotective dietary factors? Ageing Res. Rev. 11, 163-180.

Fratiglioni, L., Launer, L.J., Andersen, K., Breteler, M.M., Copeland, J.R., Dartigues, J.F., Lobo, A., Martinez-Lage, J., Soininen, H., Hofman, A., 2000. Incidence of dementia and major subtypes in Europe: a collaborative study of populationbased cohorts. Neurologic Diseases in the Elderly Research Group. Neurology 54, S10-S15.

Fruebis, J., Silvestre, M., Shelton, D., Napoli, C., Palinski, W., 1999. Inhibition of VCAM1 expression in the arterial wall is shared by structurally different antioxidants that reduce early atherosclerosis in NZW rabbits. J. Lipid Res. 40, 1958-1966.

Fuhrman, B., Volkova, N., Aviram, M., 2002. Oxidative stress increases the expression of the CD36 scavenger receptor and the cellular uptake of oxidized low-density lipoprotein in macrophages from atherosclerotic mice: protective role of antioxidants and of paraoxonase. Atherosclerosis 161, 307-316

Fulop Jr., T., Douziech, N., Larbi, A., Dupuis, G., 2002. The role of lipid rafts in T lymphocyte signal transduction with aging. Ann. N. Y. Acad. Sci. 973, 302-304.

Gaedicke, S., Zhang, X., Schmelzer, C., Lou, Y., Doering, F., Frank, J., Rimbach, G., 2008. Vitamin E dependent microRNA regulation in rat liver. FEBS Lett. 582, 3542-3546.

Goldenstein, H., Levy, N.S., Lipener, Y.T., Levy, A.P., 2013. Patient selection and vitamin E treatment in diabetes mellitus. Expert Rev. Cardiovasc. Ther. 11, 319-326.
Goodman, Y., Mattson, M.P., 1994. Secreted forms of beta-amyloid precursor protein protect hippocampal neurons against amyloid beta-peptide-induced oxidative injury. Exp. Neurol. 128, 1-12.

Goodwin, J.S., Webb, D.R., 1980. Regulation of the immune response by prostaglandins. Clin. Immunol. Immunopathol. 15, 106-122.

Graat, J.M., Schouten, E.G., Kok, F.J., 2002. Effect of daily vitamin E and multivitaminmineral supplementation on acute respiratory tract infections in elderly persons: a randomized controlled trial. JAMA 288, 715-721.

Gray, B., Swick, J., Ronnenberg, A.G., 2011. Vitamin E and adiponectin: proposed mechanism for vitamin E-induced improvement in insulin sensitivity. Nutr. Rev. 69, 155-161.

Grubic, N., Stegnar, M., Peternel, P., Kaider, A., Binder, B.R., 1996. A novel G/A and the $4 \mathrm{G} / 5 \mathrm{G}$ polymorphism within the promoter of the plasminogen activator inhibitor-1 gene in patients with deep vein thrombosis. Thromb. Res. 84 , 431-443.

Gruppo Italiano per lo Studio della Sopravvivenza nell'Infarto Miocardico. GiSS study, 1999. Dietary supplementation with n-3 polyunsaturated fatty acids and vitamin E after myocardial infarction: results of the GISSI-Prevenzione trial. Lancet 354, 447-455.

Hahn, T., Akporiaye, E.T., 2012. Repeat dose study of the novel proapoptotic chemotherapeutic agent alpha-tocopheryloxy acetic acid in mice. Anticance Drugs 23, 455-464.

Han, S.N., Meydani, S.N., 2000a. Antioxidants, cytokines, and influenza infection in aged mice and elderly humans. J. Infect. Dis. 182 (Suppl. 1), S74-S80.

Han, S.N., Meydani, M., Wu, D., Bender, B.S., Smith, D.E., Vina, J., Cao, G., Prior, R.L Meydani, S.N., 2000. Effect of long-term dietary antioxidant supplementation on influenza virus infection. J. Gerontol. A, Biol. Sci. Med. Sci. 55, B496-B503.

Hara, H., Kato, H., Kogure, K., 1990. Protective effect of alpha-tocopherol on ischemic neuronal damage in the gerbil hippocampus. Brain Res. 510, 335-338.

Harman, D., 1972. Free radical theory of aging: dietary implications. Am. J. Clin. Nutr. $25,839-843$.

Harman, D., 1980. Secondary amyloidosis and antioxidants. Lancet 2, 593.

Harman, D., 2009. Origin and evolution of the free radical theory of aging: a brief personal history, 1954-2009. Biogerontology 10, 773-781.

Harrington, L.A., Harley, C.B., 1988. Effect of vitamin E on lifespan and reproduction in Caenorhabditis elegans. Mech. Ageing Dev. 43, 71-78.

Hayek, M.G., Taylor, S.F., Bender, B.S., Han, S.N., Meydani, M., Smith, D.E., Eghtesada S., Meydani, S.N., 1997. Vitamin E supplementation decreases lung virus titers in mice infected with influenza. J. Infect. Dis. 176, 273-276.

Hemila, H., Kaprio, J., 2004. Vitamin E and respiratory tract infections in elderly persons. JAMA 292, 2834, author reply 2834.

Hemila, H., Kaprio, J., 2008. Vitamin E supplementation may transiently increase tuberculosis risk in males who smoke heavily and have high dietary vitamin C intake. Br. J. Nutr. 100, 896-902.

Hemila, H., Kaprio, J., 2009. Modification of the effect of vitamin E supplementation on the mortality of male smokers by age and dietary vitamin C. Am. J. Epidemiol. 169, 946-953.

Hemila, H., Virtamo, J., Albanes, D., Kaprio, J., 2004. Vitamin E and beta-carotene supplementation and hospital-treated pneumonia incidence in male smokers. Chest 125, 557-565.

Hemila, H., Kaprio, J., 2011. Vitamin E may affect the life expectancy of men, depending on dietary vitamin $C$ intake and smoking. Age Ageing 40, 215-220.

Hodis, H.N., Mack, W.J., LaBree, L., Mahrer, P.R., Sevanian, A., Liu, C.R., Liu, C.H., Hwang J., Selzer, R.H., Azen, S.P., VEAPS Research Group, 2002. Alpha-tocopherol supplementation in healthy individuals reduces low-density lipoprotein oxidation but not atherosclerosis: the Vitamin E Atherosclerosis Prevention Study (VEAPS). Circulation 106, 1453-1459.

Hsiao, K.K., 1995. Understanding the biology of beta-amyloid precursor proteins in transgenic mice. Neurobiol. Aging 16, 705-706.

Huang, H.Y. Helzlsouer, K.J., Appel, L.J., 2000. The effects of vitamin C and vitamin E on oxidative DNA damage: results from a randomized controlled trial. Cance Epidemiol. Biomarkers Prev. 9, 647-652.

Huebbe, P., Jofre-Monseny, L., Boesch-Saadatmandi, C., Minihane, A.M., Rimbach, G. 2007. Effect of apoE genotype and vitamin $E$ on biomarkers of oxidative stres in cultured neuronal cells and the brain of targeted replacement mice. J. Physiol Pharmacol. 58, 683-698.

Ichitani, Y., Okaichi, H., Yoshikawa, T., Ibata, Y., 1992. Learning behaviour in chronic vitamin E-deficient and -supplemented rats: radial arm maze learning and passive avoidance response. Behav. Brain Res. 51, 157-164.

Irizarry, M.C., Raman, R., Schwarzschild, M.A., Becerra, L.M., Thomas, R.G., Peterson, R.C., Ascherio, A., Aisen, P.S., 2009. Plasma urate and progression of mild cognitive impairment. Neurodegener. Dis. 6, 23-28.

Iuliano, L., Mauriello, A., Sbarigia, E., Spagnoli, L.G., Violi, F., 2000. Radiolabeled native low-density lipoprotein injected into patients with carotid stenosis accumulate in macrophages of atherosclerotic plaque: effect of vitamin E supplementation. Circulation 101, 1249-1254.

Jiang, Q., Christen, S., Shigenaga, M.K., Ames, B.N., 2001. Gamma-tocopherol, the major form of vitamin $\mathrm{E}$ in the US diet, deserves more attention. Am. J. Clin. Nutr. 74, 714-722.

Jiang, Q., Elson-Schwab, I., Courtemanche, C., Ames, B.N., 2000. Gamma-tocophero and its major metabolite, in contrast to alpha-tocopherol, inhibit cyclooxygenase activity in macrophages and epithelial cells. Proc. Natl. Acad. Sci. U.S.A. 97, 11494-11499.

Jofre-Monseny, L., de Pascual-Teresa, S., Plonka, E., Huebbe, P., Boesch-Saadatmandi, C. Minihane, A.M., Rimbach, G., 2007. Differential effects of apolipoprotein E3 and E4 on markers of oxidative status in macrophages. Br. J. Nutr. 97, 864-871. 
Jofre-Monseny, L., Minihane, A.M., Rimbach, G., 2008. Impact of apoE genotype on oxidative stress, inflammation and disease risk. Mol. Nutr. Food Res. 52, $131-145$.

Ju, J., Picinich, S.C., Yang, Z., Zhao, Y., Suh, N., Kong, A.N., Yang, C.S., 2010. Cancer-preventive activities of tocopherols and tocotrienols. Carcinogenesis 31, 533-542.

Kaga, E., Karademir, B., Baykal, A.T., Ozer, N.K., 2013. Identification of differentially expressed proteins in atherosclerotic aorta and effect of vitamin E. J. Proteomics 92, 260-273.

Kamal-Eldin, A., Appelqvist, L.A., 1996. The chemistry and antioxidant properties of tocopherols and tocotrienols. Lipids 31, 671-701.

Kamat, J.P., Devasagayam, T.P., 1995. Tocotrienols from palm oil as potent inhibitors of lipid peroxidation and protein oxidation in rat brain mitochondria. Neurosci. Lett. 195, 179-182.

Kamat, J.P., Sarma, H.D., Devasagayam, T.P., Nesaretnam, K., Basiron, Y., 1997 Tocotrienols from palm oil as effective inhibitors of protein oxidation and lipid peroxidation in rat liver microsomes. Mol. Cell. Biochem. 170, 131-137.

Kanaya, Y., Doi, T., Sasaki, H., Fujita, A., Matsuno, S., Okamoto, K., Nakano, Y., Tsujiwaki, S., Furuta, H., Nishi, M., Tsuno, T., Taniguchi, H., Nanjo, K., 2004. Rice bran extract prevents the elevation of plasma peroxylipid in KKAy diabetic mice. Diabetes Res. Clin. Pract. 66 (Suppl. 1), S157-S160.

Karasu, C., Ozansoy, G., Bozkurt, O., Erdoğan, D., Omeroğlu, S., 1997. Antioxidant and triglyceride-lowering effects of vitamin E associated with the prevention of abnormalities in the reactivity and morphology of aorta from streptozotocindiabetic rats. Antioxidants in Diabetes-Induced Complications (ADIC) Study Group. Metabolism 46, 872-879.

Kataja-Tuomola, M.K., Kontto, J.P., Mannisto, S., Albanes, D., Virtamo, J., 2011. Intake of antioxidants and risk of type 2 diabetes in a cohort of male smokers. Eur. J. Clin. Nutr. 65, 590-597.

Kato, E., Sasaki, Y., Takahashi, N., 2011. Sodium dl- $\alpha$-tocopheryl-6-O-phosphate inhibits $\mathrm{PGE}_{2}$ production in keratinocytes induced by UVB, IL-1 $\beta$ and peroxidants. Bioorg. Med. Chem. 19, 6348-6355.

Klein, E.A., Thompson Jr., I.M., Tangen, C.M., Crowley, J.J., Lucia, M.S., Goodman, P.J., Minasian, L.M., Ford, L.G., Parnes, H.L., Gaziano, J.M., Karp, D.D., Lieber, M.M. Walther, P.J., Klotz, L., Parsons, J.K., Chin, J.L., Darke, A.K., Lippman, S.M., Goodman, G.E., Meyskens Jr., F.L., Baker, L.H., 2011. Vitamin E and the risk of prostate cancer: the Selenium and Vitamin E Cancer Prevention Trial (SELECT). JAMA 306 1549-1556.

Koppal, T., Subramaniam, R., Drake, J., Prasad, M.R., Dhillon, H., Butterfield, D.A., 1998. Vitamin E protects against Alzheimer's amyloid peptide (25-35)-induced changes in neocortical synaptosomal membrane lipid structure and composition. Brain Res. 786, 270-273.

Kowdley, K.V., Mason, J.B., Meydani, S.N., Cornwall, S., Grand, R.J., 1992. Vitamin E deficiency and impaired cellular immunity related to intestinal fat malabsorption. Gastroenterology 102, 2139-2142.

Kuusisto, J., Laakso, M., 2013. Update on type 2 diabetes as a cardiovascular disease risk equivalent. Curr. Cardiol. Rep. 15, 331-335.

Lagrost, L., Desrumaux, C., Masson, D., Deckert, V., Gambert, P., 1998. Structure and function of the plasma phospholipid transfer protein. Curr. Opin. Lipidol. 9, 203-209.

Landrier, J.F., Gouranton, E., El Yazidi, C., Malezet, C., Balaguer, P., Borel, P., Amiot, M.J., 2009. Adiponectin expression is induced by vitamin $\mathrm{E}$ via a peroxisome proliferator-activated receptor gamma-dependent mechanism. Endocrinology 150, 5318-5325.

Larbi, A., Kempf, J., Pawelec, G., 2007. Oxidative stress modulation and T cell activation. Exp. Gerontol. 42, 852-858.

Lee, I.M., Cook, N.R., Gaziano, J.M., Gordon, D., Ridker, P.M., Manson, J.E., Hennekens, C.H., Buring, J.E., 2005. Vitamin E in the primary prevention of cardiovascular disease and cancer: the Women's Health Study: a randomized controlled trial. JAMA 294, 56-65.

Lemaire-Ewing, S., Desrumaux, C., Neel, D., Lagrost, L., 2010. Vitamin E transport, membrane incorporation and cell metabolism: is alpha-tocopherol in lipid rafts an oar in the lifeboat? Mol. Nutr. Food Res. 54, 631-640.

Leuner, K., Pantel, J., Frey, C., Schindowski, K., Schulz, K., Wegat, T., Maurer, K., Eckert, A., Muller, W.E., 2007. Enhanced apoptosis, oxidative stress and mitochondrial dysfunction in lymphocytes as potential biomarkers for Alzheimer's disease. J. Neural Transm. 72, 207-215.

Levy, A.P., Asleh, R., Blum, S., Levy, N.S., Miller-Lotan, R., Kalet-Litman, S., Anbinder, Y., Lache, O., Nakhoul, F.M., Asaf, R., Farbstein, D., Pollak, M., Soloveichik, Y.Z., Strauss, M., Alshiek, J., Livshits, A., Schwartz, A., Awad, H., Jad, K., Goldenstein, H., 2010. Haptoglobin: basic and clinical aspects. Antioxid. Redox Signal. 12, 293-304.

Lin, M.T., Beal, M.F., 2006. Alzheimer's APP mangles mitochondria. Nat. Med. 12, 1241-1243.

Liochev, S.I., 2013. Reactive oxygen species and the free radical theory of aging. Free Radic. Biol. Med. 60, 1-4.

Lipman, R.D., Bronson, R.T., Wu, D., Smith, D.E., Prior, R., Cao, G., Han, S.N., Martin, K.R., Meydani, S.N., Meydani, M., 1998. Disease incidence and longevity are unaltered by dietary antioxidant supplementation initiated during middle age in C57BL/6 mice. Mech. Ageing Dev. 103, 269-284.

Lippman, S.M., Klein, E.A., Goodman, P.J., Lucia, M.S., Thompson, I.M., Ford, L.G., Parnes, H.L., Minasian, L.M., Gaziano, J.M., Hartline, J.A., Parsons, J.K., Bearden 3rd, J.D., Crawford, E.D., Goodman, G.E., Claudio, J., Winquist, E., Cook, E.D., Karp, D.D., Walther, P., Lieber, M.M., Kristal, A.R., Darke, A.K., Arnold, K.B., Ganz, P.A., Santella, R.M., Albanes, D., Taylor, P.R., Probstfield, J.L., Jagpal, T.J., Crowley, J.J., Meyskens Jr., F.L., Baker, L.H., Coltman Jr., C.A., 2009. Effect of selenium and vitamin E on risk of prostate cancer and other cancers: the Selenium and Vitamin E Cancer Prevention Trial (SELECT). JAMA 301, 39-51.

Lirangi, M., Meydani, M., Zingg, J.M., Azzi, A., 2012. $\alpha$-Tocopheryl-phosphate regulation of gene expression in preadipocytes and adipocytes. Biofactors 38, 450-457.

Liu, C.C., Kanekiyo, T., Xu, H., Bu, G., 2013. Apolipoprotein E and Alzheimer disease: risk, mechanisms and therapy. Nat. Rev. Neurol. 9, 106-118.

Lloret, A., Badia, M.C., Mora, N.J., Pallardo, F.V., Alonso, M.D., Vina, J., 2009. Vitamin E paradox in Alzheimer's disease: it does not prevent loss of cognition and may even be detrimental. J. Alzheimers Dis. 17, 143-149.

Lohmiller, J.J., Roellich, K.M., Toledano, A., Rabinovitch, P.S., Wolf, N.S., Grossmann, A., 1996. Aged murine T-lymphocytes are more resistant to oxidative damage due to the predominance of the cells possessing the memory phenotype. J. Gerontol. A, Biol. Sci. Med. Sci. 51, B132-B140.

Lonn, E., Bosch, J., Yusuf, S., Sheridan, P., Pogue, J., Arnold, J.M., Ross, C., Arnold, A Sleight, P., Probstfield, J., Dagenais, G.R., HOPE and HOPE-TOO Trial Investigators, 2005. Effects of long-term vitamin E supplementation on cardiovascular events and cancer: a randomized controlled trial. JAMA 293, 1338-1347.

Losonczy, K.G., Harris, T.B., Havlik, R.J., 1996. Vitamin E and vitamin C supplement use and risk of all-cause and coronary heart disease mortality in older persons: the established populations for epidemiologic studies of the elderly. Am. J. Clin. Nutr. 64, 190-196.

Lu, G., Xiao, H., Li, G.X., Picinich, S.C., Chen, Y.K., Liu, A., Lee, M.J., Loy, S., Yang, C.S., 2010. A gamma-tocopherol-rich mixture of tocopherols inhibits chemically induced lung tumorigenesis in $\mathrm{A} / \mathrm{J}$ mice and xenograft tumor growth. Carcinogenesis 31, 687-694.

Mahabir, S., Schendel, K., Dong, Y.Q., Barrera, S.L., Spitz, M.R., Forman, M.R., 2008. Dietary alpha-, beta-, gamma- and delta-tocopherols in lung cancer risk. Int. J. Cancer 123, 1173-1180.

Malatesta, M., Bertoni-Freddari, C., Fattoretti, P., Caporaloni, C., Fakan, S., Gazzanelli, G., 2003. Altered RNA structural constituents in aging and vitamin E deficiency. Mech. Ageing Dev. 124, 175-181.

Mangialasche, F., Kivipelto, M., Mecocci, P., Rizzuto, D., Palmer, K., Winblad, B. Fratiglioni, L., 2010. High plasma levels of vitamin E forms and reduced Alzheimer's disease risk in advanced age. J. Alzheimers Dis. 20, 1029-1037.

Marchioli, R., Levantesi, G., Macchia, A., Marfisi, R.M., Nicolosi, G.L., Tavazzi, L. Tognoni, G., Valagussa, F., GISSI-Prevenzione Investigators, 2006. Vitamin E increases the risk of developing heart failure after myocardial infarction: results from the GISSI-Prevenzione trial. J. Cardiovasc. Med. 7, 347-350.

Marko, M.G., Ahmed, T., Bunnell, S.C., Wu, D., Chung, H., Huber, B.T., Meydani, S.N., 2007. Age-associated decline in effective immune synapse formation of CD4(+) T cells is reversed by vitamin E supplementation. J. Immunol. 178, 1443-1449.

Martin, A., Foxall, T., Blumberg, J.B., Meydani, M., 1997. Vitamin E inhibits lowdensity lipoprotein-induced adhesion of monocytes to human aortic endothelial cells in vitro. Arterioscler. Thromb. Vasc. Biol. 17, 429-436.

Mattson, M.P., 2004. Pathways towards and away from Alzheimer's disease. Nature 430, 631-639.

Mazlan, M., Sue Mian, T., Mat Top, G., Zurinah Wan Ngah, W., 2006. Comparative effects of alpha-tocopherol and gamma-tocotrienol against hydrogen peroxide induced apoptosis on primary-cultured astrocytes. J. Neurol. Sci. 243, 5-12.

Mecocci, P., Polidori, M.C., Troiano, L., Cherubini, A., Cecchetti, R., Pini, G., Straatman, M., Monti, D., Stahl, W., Sies, H., Franceschi, C., Senin, U., 2000. Plasma antioxidants and longevity: a study on healthy centenarians. Free Radic. Biol. Med. 28 1243-1248.

Meier, M., King, G.L., 2000. Protein kinase C activation and its pharmacological inhibition in vascular disease. Vasc. Med. 5, 173-185.

Meydani, M. 1995. Vitamin E. Lancet 345, 170-175.

Meydani, M., 2001. Vitamin E and atherosclerosis: beyond prevention of LDL oxidation. J. Nutr. 131, 366S-368S.

Meydani, M., Macauley, J.B., Blumberg, J.B., 1988. Effect of dietary vitamin E and selenium on susceptibility of brain regions to lipid peroxidation. Lipids 23, 405-409.

Meydani, S.N., Barklund, M.P., Liu, S., Meydani, M., Miller, R.A., Cannon, J.G., Morrow F.D., Rocklin, R., Blumberg, J.B., 1990a. Vitamin E supplementation enhances cellmediated immunity in healthy elderly subjects. Am. J. Clin. Nutr. 52, 557-563.

Meydani, S.N., Han, S.N., Hamer, D.H., 2004. Vitamin E and respiratory infection in the elderly. Ann. N. Y. Acad. Sci. 1031, 214-222.

Meydani, S.N., Han, S.N., Wu, D., 2005. Vitamin E and immune response in the aged: molecular mechanisms and clinical implications. Immunol. Rev. 205, 269-284.

Meydani, S.N., Meydani, M., Blumberg, J.B., 1990b. Antioxidants and the aging immune response. Adv. Exp. Med. Biol. 262, 57-67.

Meydani, S.N., Meydani, M., Blumberg, J.B., Leka, L.S., Pedrosa, M., Diamond, R. Schaefer, E.J., 1998. Assessment of the safety of supplementation with different amounts of vitamin $\mathrm{E}$ in healthy older adults. Am. J. Clin. Nutr. 68, 311-318.

Meydani, S.N., Meydani, M., Blumberg, J.B., Leka, L.S., Siber, G., Loszewski, R. Thompson, C., Pedrosa, M.C., Diamond, R.D., Stollar, B.D., 1997. Vitamin E supplementation and in vivo immune response in healthy elderly subjects. A randomized controlled trial. JAMA 277, 1380-1386.

Miller 3rd., E.R., Erlinger, T.P., Sacks, F.M., Svetkey, L.P., Charleston, J., Lin, P.H., Appel, L.J., 2005a. A dietary pattern that lowers oxidative stress increases antibodies to oxidized LDL: results from a randomized controlled feeding study. Atherosclerosis $183,175-182$.

Miller 3rd., E.R., Pastor-Barriuso, R., Dalal, D., Riemersma, R.A., Appel, L.J., Guallar, E., 2005b. Meta-analysis: high-dosage vitamin E supplementation may increase all-cause mortality. Ann. Intern. Med. 142, 37-46.

Milman, U., Blum, S., Shapira, C., Aronson, D., Miller-Lotan, R., Anbinder, Y., Alshiek, J. Bennett, L., Kostenko, M., Landau, M., Keidar, S., Levy, Y., Khemlin, A., Radan, A., Levy, A.P., 2008. Vitamin E supplementation reduces cardiovascular events 
in a subgroup of middle-aged individuals with both type 2 diabetes mellitus and the haptoglobin 2-2 genotype: a prospective double-blinded clinical trial. Arterioscler. Thromb. Vasc. Biol. 28, 341-347.

Mocchegiani, E., Costarelli, L., Giacconi, R., Piacenza, F., Basso, A., Malavolta, M., 2012. Micronutrient $(\mathrm{Zn}, \mathrm{Cu}, \mathrm{Fe})$-gene interactions in ageing and inflammatory agerelated diseases: implications for treatments. Ageing Res. Rev. 11, 297-319.

Mocchegiani, E., Giacconi, R., Cipriano, C., Muzzioli, M., Gasparini, N., Moresi, R., Stecconi, R., Suzuki, H., Cavalieri, E., Mariani, E., 2002. MtmRNA gene expression, via IL-6 and glucocorticoids, as potential genetic marker of immunosenescence: lessons from very old mice and humans. Exp. Gerontol. 37, 349-357.

Molano, A., Huang, Z., Marko, M.G., Azzi, A., Wu, D., Wang, E., Kelly, S.L., Merrill Jr. A.H., Bunnell, S.C., Meydani, S.N., 2012. Age-dependent changes in the sphingolipid composition of mouse CD4+ T cell membranes and immune synapses implicate glucosylceramides in age-related $\mathrm{T}$ cell dysfunction. PLoS ONE 7, e47650.

Molano, A., Meydani, S.N., 2012. Vitamin E, signalosomes and gene expression in T cells. Mol. Aspects Med. 33, 55-62.

Monji, A., Morimoto, N., Okuyama, I., Yamashita, N., Tashiro, N., 1994. Effect of dietary vitamin $\mathrm{E}$ on lipofuscin accumulation with age in the rat brain. Brain Res. 634, 62-68.

Morley, A.A., Trainor, K.J., 2001. Lack of an effect of vitamin E on lifespan of mice. Biogerontology 2, 109-112.

Morris, M.C., 2012. Nutritional determinants of cognitive aging and dementia. Proc. Nutr. Soc. 71, 1-13.

Morris, M.C., Evans, D.A., Tangney, C.C., Bienias, J.L., Wilson, R.S., Aggarwal, N.T. Scherr, P.A., 2005. Relation of the tocopherol forms to incident Alzheimer disease and to cognitive change. Am. J. Clin. Nutr. 81, 508-514.

Munteanu, A., Zingg J.M., Ogru, E., Libinaki, R., Gianello, R., West, S., Negis, Y., Azzi, A. 2004. Modulation of cell proliferation and gene expression by alpha-tocopheryl phosphates: relevance to atherosclerosis and inflammation. Biochem. Biophys. Res. Commun. 318, 311-316.

Mustacich, D.J., Leonard, S.W., Devereaux, M.W., Sokol, R.J., Traber, M.G., 2006. Alpha-tocopherol regulation of hepatic cytochrome P450s and ABC transporters in rats. Free Radic. Biol. Med. 41, 1069-1078.

Nanayakkara, P.W., van Guldener, C., ter Wee, P.M., Scheffer, P.G., van Ittersum, F.J., Twisk, J.W., Teerlink, T., van Dorp, W., Stehouwer, C.D., 2007. Effect of a treatment strategy consisting of pravastatin, vitamin $\mathrm{E}$, and homocysteine lowering on carotid intima-media thickness, endothelial function, and renal function in patients with mild to moderate chronic kidney disease: results from the AntiOxidant Therapy in Chronic Renal Insufficiency (ATIC) Study. Arch. Intern. Med. $167,1262-1270$

Navarro, A., Gomez, C., Sanchez-Pino, M.J., Gonzalez, H., Bandez, M.J., Boveris, A.D., Boveris, A., 2005. Vitamin E at high doses improves survival, neurological performance, and brain mitochondrial function in aging male mice. Am. J. Physiol. Regul. Integr. Comp. Physiol. 289, R1392-R1399.

Nesaretnam, K. Guthrie, N. Chambers, A.F. Carroll, K.K. 1995. Effect of tocotrienols on the growth of a human breast cancer cell line in culture. Lipids 30, 1139-1143. Nesaretnam, K., Stephen, R., Dils, R., Darbre, P., 1998. Tocotrienols inhibit the growth of human breast cancer cells irrespective of estrogen receptor status. Lipids 33, 461-469.

Niki, E., Traber, M.G., 2012. A history of vitamin E. Ann. Nutr. Metab. 61, 207-212.

O'Donnell, E., Lynch, M.A., 1998. Dietary antioxidant supplementation reverses agerelated neuronal changes. Neurobiol. Aging 19, 461-467.

O'Leary, K.A., de Pascual-Tereasa, S., Needs, P.W., Bao, Y.P., O'Brien, N.M., Williamson, G., 2004. Effect of flavonoids and vitamin E on cyclooxygenase-2 (COX-2) transcription. Mutation Res. 551, 245-254.

Ozen, M., Creighton, C.J., Ozdemir, M., Ittmann, M., 2008. Widespread deregulation of microRNA expression in human prostate cancer. Oncogene 27, 1788-1793.

Ozer, N.K., Negis, Y., Aytan, N., Villacorta, L., Ricciarelli, R., Zingg, J.M., Azzi, A., 2006. Vitamin $\mathrm{E}$ inhibits CD36 scavenger receptor expression in hypercholesterolemic rabbits. Atherosclerosis 184, 15-20.

Pae, M., Meydani, S.N., Wu, D., 2012. The role of nutrition in enhancing immunity in aging. Aging Dis. 3, 91-129.

Palace, V.P., Hill, M.F., Farahmand, F., Singal, P.K., 1999a. Mobilization of antioxidant vitamin pools and hemodynamic function after myocardial infarction. Circulation 99, 121-126.

Palace, V., Kumar, D., Hill, M.F., Khaper, N., Singal, P.K., 1999b. Regional differences in non-enzymatic antioxidants in the heart under control and oxidative stress conditions. J. Mol. Cell. Cardiol. 31, 193-202.

Pallast, E.G., Schouten, E.G., de Waart, F.G., Fonk, H.C., Doekes, G., von Blomberg, B.M., Kok, F.J., 1999. Effect of 50- and 100-mg vitamin E supplements on cellular immune function in noninstitutionalized elderly persons. Am. J. Clin. Nutr. 69, 1273-1281.

Patrignani, P., Panara, M.R., Tacconelli, S., Seta, F., Bucciarelli, T., Ciabattoni, G., Alessandrini, P., Mezzetti, A., Santini, G., Sciulli, M.G., Cipollone, F., Davi, G., Gallina, P., Bon, G.B., Patrono, C., 2000. Effects of vitamin E supplementation on $\mathrm{F}(2)$-isoprostane and thromboxane biosynthesis in healthy cigarette smokers. Circulation 102, 539-545.

Petersen, R.C., Thomas, R.G., Grundman, M., Bennett, D., Doody, R., Ferris, S., Galasko, D., Jin, S., Kaye, J., Levey, A., Pfeiffer, E., Sano, M., van Dyck, C.H., Thal, L.J., Alzheimer's Disease Cooperative Study Group, 2005. Vitamin E and donepezil for the treatment of mild cognitive impairment. N. Engl. J. Med. 352, 2379-2388. Petratos, S., Li, Q.X., George, A.J., Hou, X., Kerr, M.L., Unabia, S.E., Hatzinisiriou, I., Maksel, D., Aguilar, M.I., Small, D.H., 2008. The beta-amyloid protein of Alzheimer's disease increases neuronal CRMP-2 phosphorylation by a Rho-GTP mechanism. Brain 131, 90-108.
Peyser, C.E., Folstein, M., Chase, G.A., Starkstein, S., Brandt, J., Cockrell, J.R., Bylsma, F., Coyle, J.T., McHugh, P.R., Folstein, S.E., 1995. Trial of d-alpha-tocopherol in Huntington's disease. Am. J. Psychiatry 152, 1771-1775.

Pham, D.Q., Plakogiannis, R., 2005. Vitamin E supplementation in Alzheimer's disease, Parkinson's disease, tardive dyskinesia, and cataract: part 2. Ann. Pharmacother. 39, 2065-2072.

Phipps, R.P., Stein, S.H., Roper, R.L., 1991. A new view of prostaglandin E regulation of the immune response. Immunol. Today 12, 349-352.

Pierpaoli, E., Viola, V., Barucca, A., Orlando, F., Galli, F., Provinciali, M., 2013. Effect of annatto-tocotrienols supplementation on the development of mammary tumors in HER-2/neu transgenic mice. Carcinogenesis 34, 1352-1360.

Pierpaoli, E., Viola, V., Pilolli, F., Piroddi, M., Galli, F., Provinciali, M., 2010. Gammaand delta-tocotrienols exert a more potent anticancer effect than alphatocopheryl succinate on breast cancer cell lines irrespective of HER-2/neu expression. Life Sci. 86, 668-675.

Poljsak, B., Milisav, I., 2012. The neglected significance of "antioxidative stress". Oxid. Med. Cell. Longev. 2012, 480895-480907.

Pratico, D., Tangirala, R.K., Rader, D.J., Rokach, J., FitzGerald, G.A., 1998. Vitamin E suppresses isoprostane generation in vivo and reduces atherosclerosis in ApoEdeficient mice. Nat. Med. 4, 1189-1192.

Puglielli, L., Tanzi, R.E., Kovacs, D.M., 2003. Alzheimer's disease: the cholesterol connection. Nat. Neurosci. 6, 345-351.

Qureshi, A.A., Sami, S.A., Salser, W.A., Khan, F.A., 2001. Synergistic effect of tocotrienol-rich fraction (TRF(25)) of rice bran and lovastatin on lipid parameters in hypercholesterolemic humans. J. Nutr. Biochem. 12, 318-329.

Qureshi, A.A., Qureshi, N., Hasler-Rapacz, J.O., Weber, F.E., Chaudhary, V., Crenshaw T.D., Gapor, A., Ong, A.S., Chong, Y.H., Peterson, D., 1991. Dietary tocotrienols reduce concentrations of plasma cholesterol, apolipoprotein $B$, thromboxane $B 2$, and platelet factor 4 in pigs with inherited hyperlipidemias. Am. J. Clin. Nutr. 53, 1042S-1046S.

Reiter, E., Jiang, Q., Christen, S., 2007. Anti-inflammatory properties of alpha- and gamma-tocopherol. Mol. Aspects Med. 28, 668-691.

Ricciarelli, R., Zingg, J.M., Azzi, A., 2000. Vitamin E reduces the uptake of oxidized LDL by inhibiting CD36 scavenger receptor expression in cultured aortic smooth muscle cells. Circulation 102, 82-87.

Rigotti, A., 2007. Absorption, transport, and tissue delivery of vitamin E. Mol. Aspects Med. 28, 423-436.

Rimbach, G., Fischer, A., Stoecklin, E., Barella, L., 2004. Modulation of hepatic gene expression by alpha-tocopherol in cultured cells and in vivo. Ann. N. Y. Acad. Sci. 1031, 102-108.

Rimbach, G., Moehring, J., Huebbe, P., Lodge, J.K., 2010. Gene-regulatory activity of alpha-tocopherol. Molecules 15, 1746-1761.

Rimm, E.B., Stampfer, M.J., Ascherio, A., Giovannucci, E., Colditz, G.A., Willett, W.C., 1993. Vitamin $\mathrm{E}$ consumption and the risk of coronary heart disease in men. $\mathrm{N}$. Engl. J. Med. 328, 1450-1456.

Robinson, C., Woo, S., Walsh, A., Nowak, A.K., Lake, R.A., 2012. The antioxidants vitamins $\mathrm{A}$ and $\mathrm{E}$ and selenium do not reduce the incidence of asbestos-induced disease in a mouse model of mesothelioma. Nutr. Cancer 64, 315-322.

Rota, C., Rimbach, G., Minihane, A.M., Stoecklin, E., Barella, L., 2005. Dietary vitamin $\mathrm{E}$ modulates differential gene expression in the rat hippocampus: potential implications for its neuroprotective properties. Nutr. Neurosci. 8, 21-29.

Sabat, R., Kolleck, I., Witt, W., Volk, H., Sinha, P., Rustow, B., 2001. Immunological dysregulation of lung cells in response to vitamin E deficiency. Free Radic. Biol. Med. 30, 1145-1153.

Saito, Y., Nishio, K., Akazawa, Y.O., Yamanaka, K., Miyama, A., Yoshida, Y., Noguchi, N. Niki, E., 2010. Cytoprotective effects of vitamin E homologues against glutamateinduced cell death in immature primary cortical neuron cultures: tocopherols and tocotrienols exert similar effects by antioxidant function. Free Radic. Biol. Med. 49, 1542-1549.

Salonen, J.T., Nyyssönen, K., Salonen, R., Lakka, H.M., Kaikkonen, J., PorkkalaSarataho, E., Voutilainen, S., Lakka, T.A., Rissanen, T., Leskinen, L., Tuomainen, T.P., Valkonen, V.P., Ristonmaa, U., Poulsen, H.E., 2000. Antioxidant supplementation in atherosclerosis prevention (ASAP) study: a randomized trial of the effect of vitamins $E$ and $C$ on 3-year progression of carotid atherosclerosis. J. Intern. Med. 248, 377-386.

Salonen, R.M., Nyyssönen, K., Kaikkonen, J., Porkkala-Sarataho, E., Voutilainen, S. Rissanen, T.H., Tuomainen, T.P., Valkonen, V.P., Ristonmaa, U., Lakka, H.M. Vanharanta, M., Salonen, J.T., Poulsen, H.E., Antioxidant Supplementation in Atherosclerosis Prevention Study, 2003. Six-year effect of combined vitamin $\mathrm{C}$ and $\mathrm{E}$ supplementation on atherosclerotic progression: the Antioxidant Supplementation in Atherosclerosis Prevention (ASAP) Study. Circulation 107 947-953.

Sanchez, C., Perez, M., Avila, J., 2000. GSK3beta-mediated phosphorylation of the microtubule-associated protein $2 \mathrm{C}$ (MAP2C) prevents microtubule bundling. Eur. J. Cell Biol. 79, 252-260.

Sano, M., Ernesto, C., Thomas, R.G., Klauber, M.R., Schafer, K., Grundman, M., Woodbury, P., Growdon, J., Cotman, C.W., Pfeiffer, E., Schneider, L.S., Thal, L.J., 1997. A controlled trial of selegiline, alpha-tocopherol, or both as treatment for Alzheimer's disease. The Alzheimer's Disease Cooperative Study. N. Engl. J. Med. 336, 1216-1222.

Saremi, A., Arora, R., 2010. Vitamin E and cardiovascular disease. Am. J. Ther. 17, e56-e65.

Sesso, H.D., Buring, J.E., Christen, W.G., Kurth, T., Belanger, C., MacFadyen, J., Bubes, V., Manson, J.E., Glynn, R.J., Gaziano, J.M., 2008. Vitamins E and C in the prevention of cardiovascular disease in men: the Physicians' Health Study II randomized controlled trial. JAMA 300, 2123-2133.

1977

1978

\section{0}

2034

203

2037 
Singal, P.K., Khaper, N., Palace, V., Kumar, D., 1998. The role of oxidative stress in the genesis of heart disease. Cardiovasc. Res. 40, 426-432

Sirikci, O., Ozer, N.K., Azzi, A., 1996. Dietary cholesterol-induced changes of protein kinase $C$ and the effect of vitamin $E$ in rabbit aortic smooth muscle cells. Atherosclerosis 126, 253-263.

Slevin, M., Krupinski, J., Badimon, L., 2009. Controlling the angiogenic switch in developing atherosclerotic plaques: possible targets for therapeutic intervention. J. Angiogenes Res. 21, 1-4.

Socci, D.J., Crandall, B.M., Arendash, G.W., 1995. Chronic antioxidant treatment improves the cognitive performance of aged rats. Brain Res. 693, 88-94.

Squier, T.C., 2001. Oxidative stress and protein aggregation during biological aging. Exp. Gerontol. 36, 1539-1550.

Stampfer, M.J., Hennekens, C.H., Manson, J.E., Colditz, G.A., Rosner, B., Willett, W.C. 1993. Vitamin $\mathrm{E}$ consumption and the risk of coronary disease in women. $\mathrm{N}$ Engl. J. Med. 328, 1444-1449.

Stephens, N.G., Parsons, A., Schofield, P.M., Kelly, F., Cheeseman, K., Mitchinson, M.J., 1996. Randomised controlled trial of vitamin $\mathrm{E}$ in patients with coronary disease: Cambridge Heart Antioxidant Study (CHAOS). Lancet 347, 781-786.

Strittmatter, W.J., Roses, A.D., 1996. Apolipoprotein E and Alzheimer's disease. Annu. Rev. Neurosci. 19, 53-77.

Suzuki, Y.J., Packer, L., 1993. Inhibition of NF-kappa B activation by vitamin E derivatives. Biochem. Biophys. Res. Commun. 193, 277-283.

Tanzi, R.E., Bertram, L., 2001. New frontiers in Alzheimer's disease genetics. Neuron $32,181-184$

Tasinato, A., Boscoboinik, D., Bartoli, G.M., Maroni, P., Azzi, A., 1995. d-alphatocopherol inhibition of vascular smooth muscle cell proliferation occurs at physiological concentrations, correlates with protein kinase $C$ inhibition, and is independent of its antioxidant properties. Proc. Natl. Acad. Sci. U.S.A. 92, 12190-12194.

Terasawa, Y., Manabe, H., Yoshida, N., Uemura, M., Sugimoto, N., Naito, Y., Yoshikawa, T., Kondo, M., 2000. Alpha-tocopherol protects against monocyte Mac-1 (CD11b/CD18) expression and Mac-1-dependent adhesion to endothelial cells induced by oxidized low-density lipoprotein. Biofactors 11, 221-233.

Testa, R., Bonfigli, A.R., Sirolla, C., Boemi, M., Manfrini, S., Mari, D., Testa, I., Sacchi, E., Franceschi, C., 2004. Effect of 4G/5G PAI-1 polymorphism on the response of PAI-1 activity to vitamin E supplementation in Type 2 diabetic patients. Diabetes Nutr. Metab. 17, 217-221.

Theriault, A., Chao, J.T., Wang, Q., Gapor, A., Adeli, K., 1999. Tocotrienol: a review of its therapeutic potential. Clin. Biochem. 32, 309-319.

Thomas, D.R., 2006. Vitamins in aging, health, and longevity. Clin. Interv. Aging 1, 81-91.

Tili, E., Michaille, J.J., Cimino, A., Costinean, S., Dumitru, C.D., Adair, B., Fabbri, M., Alder, H., Liu, C.G., Calin, G.A., Croce, C.M., 2007. Modulation of miR-155 and miR-125b levels following lipopolysaccharide/TNF-alpha stimulation and their possible roles in regulating the response to endotoxin shock. J. Immunol. 179, 5082-5089.

Tiwari, V., Kuhad, A., Bishnoi, M., Chopra, K., 2009. Chronic treatment with tocotrienol, an isoform of vitamin $\mathrm{E}$, prevents intracerebroventricular streptozotocin-induced cognitive impairment and oxidative-nitrosative stress in rats. Pharmacol. Biochem. Behav. 93, 183-189.

Traber, M.G., Kayden, H.J., 1989. Preferential incorporation of alpha-tocopherol vs gamma-tocopherol in human lipoproteins. Am. J. Clin. Nutr. 49, 517-526.

Tseng, C.F., Lin, C.C., Huang, H.Y., Liu, H.C., Mao, S.J., 2004. Antioxidant role of human haptoglobin. Proteomics 4, 2221-2228.

Usoro, O.B., Mousa, S.A., 2010. Vitamin E forms in Alzheimer's disease: a review of controversial and clinical experiences. Crit. Rev. Food Sci. Nutr. 50, 414-419.

van Amsterdam, J., van der Horst-Graat, J., Bischoff, E., Steerenberg, P., Opperhuizen, A., Schouten, E., 2005. The effect of vitamin E supplementation on serum DHEA and neopterin levels in elderly subjects. Int. J. Vitam. Nutr. Res. 75, 327-331.

Vardi, M., Blum, S., Levy, A.P., 2012. Haptoglobin genotype and cardiovascular outcomes in diabetes mellitus - natural history of the disease and the effect of vitamin E treatment. Meta-analysis of the medical literature. Eur. J. Int. Med. 23 628-632.

Villanueva, C., Kross, R.D., 2012. Antioxidant-induced stress. Int. J. Mol. Sci. 13, 2091-2109.

Vina, J., Borras, C., Mohamed, K., Garcia-Valles, R., Gomez-Cabrera, M.C., 2013. The free radical theory of ageing revisited. The cell signaling disruption theory of aging. Antioxid. Redox Signal. 19, 779-787.

Viola, V., Pilolli, F., Piroddi, M., Pierpaoli, E., Orlando, F., Provinciali, M., Betti, M., Mazzini, F., Galli, F., 2012. Why tocotrienols work better: insights into the in vitro anti-cancer mechanism of vitamin E. Genes Nutr. 7, 29-41.
Virtamo, J., Rapola, J.M., Ripatti, S., Heinonen, O.P., Taylor, P.R., Albanes, D., Huttunen, J.K., 1998. Effect of vitamin $\mathrm{E}$ and beta carotene on the incidence of primary nonfatal myocardial infarction and fatal coronary heart disease. Arch. Intern. Med. 158, 668-675.

Voegele, A.F., Jerković, L., Wellenzohn, B., Eller, P., Kronenberg, F., Liedl, K.R., Dieplinger, H., 2002. Characterization of the vitamin E-binding properties of human plasma afamin. Biochemistry 41, 14532-14538.

Wan Nazaimoon, W.M., Khalid, B.A., 2002. Tocotrienols-rich diet decreases advanced glycosylation end-products in non-diabetic rats and improves glycemic control in streptozotocin-induced diabetic rats. Malays. J. Pathol. 24, 77-82.

Waters, D.D., Alderman, E.L., Hsia, J., Howard, B.V., Cobb, F.R., Rogers, W.J., Ouyang P., Thompson, P., Tardif, J.C., Higginson, L., Bittner, V., Steffes, M., Gordon, D.J., Proschan, M., Younes, N., Verter, J.I., 2002. Effects of hormone replacement therapy and antioxidant vitamin supplements on coronary atherosclerosis in postmenopausal women: a randomized controlled trial. JAMA 288, 2432-2440.

Way, K.J., Katai, N., King, G.L., 2001. Protein kinase C and the development of diabetic vascular complications. Diabetic Med. 18, 945-959.

Webb, D.R., Rogers, T.J., Ong, S., Steiner, A., 1980. Detection of prostaglandin induced antigen-stimulated changes in splenic AMP levels by immunofluorescence. Prostaglandins Med. 5, 141-148.

Weber, P., Bendich, A., Machlin, L.J., 1997. Vitamin E and human health: rationale for determining recommended intake levels. Nutrition 13, 450-460.

Wigg, S.J., Tare, M., Forbes, J., Cooper, M.E., Thomas, M.C., Coleman, H.A., Parkington, H.C., O'Brien, R.C., 2004. Early vitamin E supplementation attenuates diabetes-associated vascular dysfunction and the rise in protein kinase C-beta in mesenteric artery and ameliorates wall stiffness in femoral artery of Wistar rats. Diabetologia 47, 1038-1046.

Wolvers, D.A., van Herpen-Broekmans, W.M., Logman, M.H., van der Wielen, R.P., Albers, R., 2006. Effect of a mixture of micronutrients, but not of bovine colostrum concentrate, on immune function parameters in healthy volunteers: a randomized placebo-controlled study. Nutr. J. 5, 28-35.

Wortwein, G., Stackman, R.W., Walsh, T.J., 1994. Vitamin E prevents the place learning deficit and the cholinergic hypofunction induced by AF64A. Exp. Neurol. 125 15-21.

Wray, D.W., Nishiyama, S.K., Harris, R.A., Zhao, J., McDaniel, J., Fjeldstad, A.S., Witman, M.A., Ives, S.J., Barrett-O'Keefe, Z., Richardson, R.S., 2012. Acute reversa of endothelial dysfunction in the elderly after antioxidant consumption. Hypertension 59, 818-824.

Wu, D., Meydani, S.N., 2008. Age-associated changes in immune and inflammatory responses: impact of vitamin E intervention. J. Leukoc. Biol. 84, 900-914.

Wu, D., Koga, T., Martin, K.R., Meydani, M., 1999. Effect of vitamin E on human aortic endothelial cell production of chemokines and adhesion to monocytes. Atherosclerosis 147, 297-307.

Wu, D., Mura, C., Beharka, A.A., Han, S.N., Paulson, K.E., Hwang, D., Meydani, S.N., 1998. Age-associated increase in PGE2 synthesis and COX activity in murine macrophages is reversed by vitamin E. Am. J. Physiol. 275, C661-C668.

Yamaoka, S., Kim, H.S., Ogihara, T., Oue, S., Takitani, K., Yoshida, Y., Tamai, H., 2008 Severe Vitamin E deficiency exacerbates acute hyperoxic lung injury associated with increased oxidative stress and inflammation. Free Radic. Res. 42, 602-612.

Yang, C.S., Suh, N., 2013. Cancer prevention by different forms of tocopherols. Top. Curr. Chem. 329, 21-33

Yoshida, Y., Niki, E., Noguchi, N., 2003. Comparative study on the action of tocopherols and tocotrienols as antioxidant: chemical and physical effects. Chem. Phys. Lipids $123,63-75$

Yusuf, S., Dagenais, G., Pogue, J., Bosch, J., Sleight, P., 2000. Vitamin E supplementation and cardiovascular events in high-risk patients. The Heart Outcomes Prevention Evaluation Study Investigators. N. Engl. J. Med. 342, 154-160.

Zapolska-Downar, D., Zapolski-Downar, A., Markiewski, M., Ciechanowicz, A., Kaczmarczyk, M., Naruszewicz, M., 2000. Selective inhibition by alpha-tocopherol of vascular cell adhesion molecule-1 expression in human vascular endothelia cells. Biochem. Biophys. Res. Commun. 274, 609-615.

Zhou, Y., Gopalakrishnan, V., Richardson, J.S., 1996. Actions of neurotoxic betaamyloid on calcium homeostasis and viability of PC12 cells are blocked by antioxidants but not by calcium channel antagonists. J. Neurochem. 67, 1419-1425.

Zingg, J.M., Azzi, A., Meydani, M., 2008. Genetic polymorphisms as determinants for disease-preventive effects of vitamin E. Nutr. Rev. 66, 406-414.

Zingg, J.M., Han, S.N., Pang, E., Meydani, M., Meydani, S.N., Azzi, A., 2013. In vivo regulation of gene transcription by alpha- and gamma-tocopherol in murine $T$ lymphocytes. Arch. Biochem. Biophys. 538, 111-119.

Zingg, J.M., Ricciarelli, R., Andorno, E., Azzi, A., 2002. Novel 5' exon of scavenger receptor CD36 is expressed in cultured human vascular smooth muscle cells and atherosclerotic plaques. Arterioscler. Thromb. Vasc. Biol. 22, 412-417. 